\title{
Rivers, not refugia, drove diversification in arboreal, sub-Saharan African snakes
}

\author{
Kaitlin E. Allen ${ }^{1,2}$ (D) | Eli Greenbaum ${ }^{3}$ | Paul M. Hime ${ }^{2}$ | Walter P. Tapondjou N. ${ }^{1,2}$ \\ Viktoria V. Sterkhova ${ }^{1,2}$ | Chifundera Kusamba ${ }^{4}$ | Mark-Oliver Rödel ${ }^{5}$ | \\ Johannes Penner $^{5,6}$ | A. Townsend Peterson ${ }^{1,2}$ | Rafe M. Brown ${ }^{1,2}$
}

${ }^{1}$ Department of Ecology and Evolutionary Biology, University of Kansas, Lawrence, KS, USA

${ }^{2}$ Biodiversity Institute, University of Kansas, Lawrence, KS, USA

${ }^{3}$ Department of Biological Sciences, University of Texas at El Paso, El Paso, TX, USA

${ }^{4}$ Laboratoire d'Hérpétologie, Département de Biologie, Centre de Recherche en Sciences Naturelles, Lwiro, Democratic Republic of Congo

${ }^{5}$ Museum für Naturkunde - Leibniz Institute for Evolution and Biodiversity Science, Berlin, Germany

${ }^{6}$ Chair of Wildlife Ecology and Management, University of Freiburg, Freiburg, Germany

\section{Correspondence}

Kaitlin E. Allen, Department of Ecology and Evolutionary Biology, University of Kansas, Lawrence, KS 66045, USA.

Email: kallen9@ku.edu

\section{Funding information}

University of Kansas College of Liberal Arts and Sciences; Deutsche Forschungsgemeinschaft, Grant/Award Number: DFG VE 183/4-1 and RO 3064/1-2; Division of Environmental Biology, Grant/ Award Number: 1145459, 1557053 and 1654388; Bundesministerium für Bildung und Forschung, Grant/Award Number: 01LC0017; University of Kanasas Office of Graduate Studies; Villanova University Department of Biology; The Linnean Society of London; National Geographic Society, Grant/Award Number: 8556-08 and WWR018-17; IUCN/SSC Amphibian Specialist Group Seed Grant; University of Texas El Paso; University of Kansas Biodiversity Institute

\begin{abstract}
The relative roles of rivers versus refugia in shaping the high levels of species diversity in tropical rainforests have been widely debated for decades. Only recently has it become possible to take an integrative approach to test predictions derived from these hypotheses using genomic sequencing and paleo-species distribution modeling. Herein, we tested the predictions of the classic river, refuge, and riverrefuge hypotheses on diversification in the arboreal sub-Saharan African snake genus Toxicodryas. We used dated phylogeographic inferences, population clustering analyses, demographic model selection, and paleo-distribution modeling to conduct a phylogenomic and historical demographic analysis of this genus. Our results revealed significant population genetic structure within both Toxicodryas species, corresponding geographically to river barriers and divergence times from the mid-Miocene to Pliocene. Our demographic analyses supported the interpretation that rivers are indications of strong barriers to gene flow among populations since their divergence. Additionally, we found no support for a major contraction of suitable habitat during the last glacial maximum, allowing us to reject both the refuge and river-refuge hypotheses in favor of the river-barrier hypothesis. Based on conservative interpretations of our species delimitation analyses with the Sanger and ddRAD data sets, two new cryptic species are identified from east-central Africa. This study highlights the complexity of diversification dynamics in the African tropics and the advantages of integrative approaches to studying speciation in tropical regions.
\end{abstract}

\section{KEYWORDS}

historical demography, machine learning, paleo-distributions, phylogenomics, Toxicodryas

This is an open access article under the terms of the Creative Commons Attribution License, which permits use, distribution and reproduction in any medium, provided the original work is properly cited.

(c) 2021 The Authors. Ecology and Evolution published by John Wiley \& Sons Ltd. 


\section{1 | INTRODUCTION}

Three major allopatric diversification mechanisms have been proposed in the classical literature to explain species diversity in the tropics. The "river hypothesis" in which species and populations diverged across riverine barriers (Ayres \& Clutton-Brock, 1992; Bates, 1863; Hershkovitz, 1977; Mayr, 1942; Sick, 1967; Wallace, 1853); the "refuge hypothesis" in which forests fragmented during the cold, dry Pleistocene glaciation cycles, causing isolation and divergence in small forest patches (Haffer, 1969, 1974, 1982; Prance, 1982; Vanzolini, 1973; Vanzolini \& Williams, 1970); and an amalgamate "river-refuge hypothesis," in which speciation was promoted by a combination of river barriers and climate-driven vegetation changes (Ayres \& Clutton-Brock, 1992; Haffer, 1992, 1993). These hypotheses have been widely employed as the context for studies of Neotropical biodiversity and the mechanisms of its production (e.g., Gascon et al., 2000; Haffer, 2008; Patton \& Silva, 2005; Richardson et al., 2001; Weir, 2006). However, because the early scientific focus was primarily on the Amazon (Amorim, 1991; Cracraft, 1985; DeMenocal, 2004; Haffer, 1969, 1997; Plana, 2004; but see Fjeldså, 1994; Mayr \& O'Hara, 1986) and given political instability in tropical Africa (Greenbaum, 2017; Siddig, 2019; Tolley et al., 2016), rigorous testing of the predictions stemming from these hypotheses has been neglected for the West and Central African rainforests until only recently.

Based on pollen core records (Bonnefille \& Riollet, 1988; Brenac, 1988; Girese et al., 1994; Maley, 1987, 1989, 1991; Maley \& Brénac, 1987; Maley \& Livingstone, 1983; Sowunmi, 1991) and species distribution data (Colyn, 1987, 1991; Richards, 1963; Rietkerk et al., 1995; Sosef, 1991), Maley (1996) proposed several Pleistocene rainforest refugia for sub-Saharan Africa that are still considered today (e.g., Bell et al., 2017; Hughes et al., 2017; Huntley et al., 2019; Jongsma et al., 2018; Larson et al., 2016; Penner et al., 2011; Portik et al., 2017; Figure 1). Many of these hypothesized refugia are located in highland areas (e.g., the Cameroon Volcanic Line and the Albertine Rift; Figure 1, refugia 4 and 10, respectively). However, a major fluvial refuge, that is, a refugium associated with a river, located in the gallery forests around the Congo River (Figure 1, refugium 9), has been supported by pollen core data (Maley, 1996), and distributional patterns of multiple bird (Huntley et al., 2018; Levinsky et al., 2013), mammal (Colyn et al., 1991; Levinsky et al., 2013), and plant taxa (Robbrecht, 1996).

Major river barriers in West and Central Africa include the Volta, Sanaga, Ogooué, Congo, Niger, and Cross Rivers (Figure 1). The exact ages of many of these rivers are unknown but are generally estimated to date back to the Late Mesozoic to Early Cenozoic (80-35 mya; Couvreur et al., 2021; Goudie, 2005; Stankiewicz \& de Wit, 2006). However, while the Congo basin is quite old (Flügel et al., 2015; Stankiewicz \& de Wit, 2006), the present course of the Congo River appears to be much younger, dating to the mid to late Miocene and corresponding to the uplift of the East African Rift (Flügel et al., 2015; Stankiewicz \& de Wit, 2006; Takemoto et al., 2015).

Numerous phylogeographic studies have supported the importance of rivers, refugia, or both as drivers of diversification across disparate plant and animal species. Rivers alone have been shown to be important barriers for some species of primates (Mitchell et al., 2015; Telfer et al., 2003), shrews (Jacquet et al., 2015), and frogs (Charles et al., 2018; Penner et al., 2011, 2019; Wieczorek et al., 2000; Zimkus et al., 2010), but do not appear to represent an important barrier for many plant species (Dauby et al., 2014; Debout et al., 2011; Hardy et al., 2013; Ley et al., 2014; Lowe

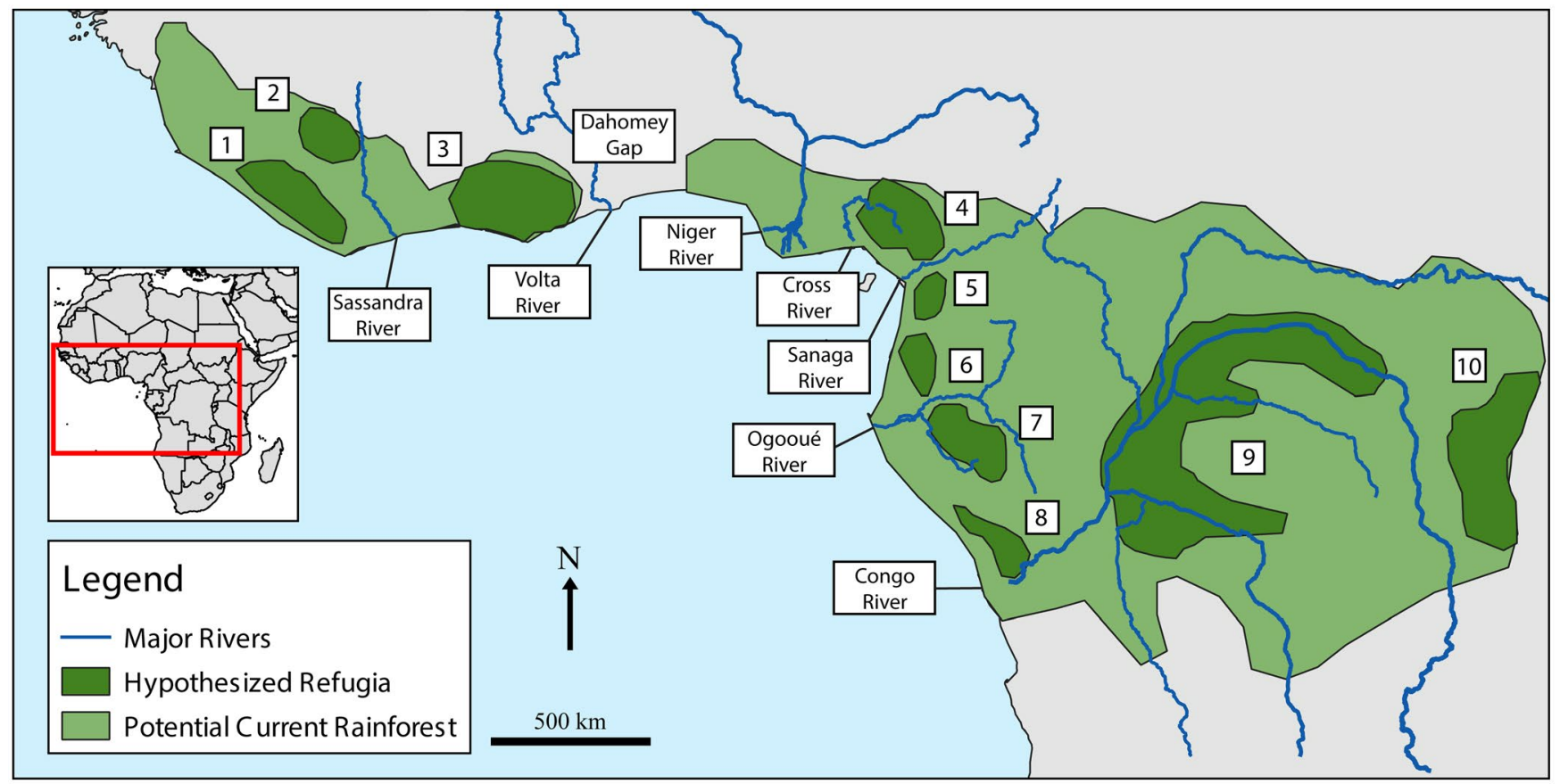

FIGURE 1 Locations of major rivers and hypothesized refugia (labeled 1-10) in West and Central Africa, adapted from Maley (1996) 


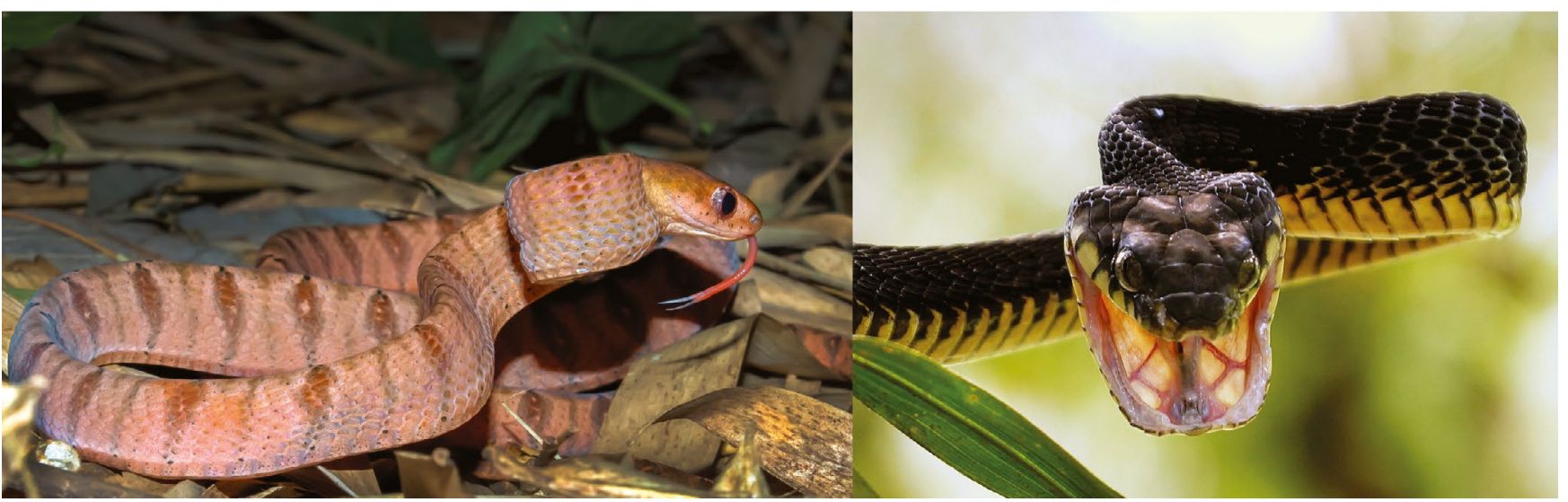

FIGURE 2 Left: Toxicodryas pulverulenta. Right: Toxicodryas blandingii (male). Both photographs were taken in Banalia, Tshopo Province, DR Congo. Photograph credits Konrad Mebert

et al., 2010). Refugia are suggested to have played an important role in the diversification of rodents (Bohoussou et al., 2015; Nicolas et al., 2011, 2012), primates (Clifford et al., 2004; Haus et al., 2013; Tosi, 2008), frogs (Bell et al., 2017; Jongsma et al., 2018), lizards (Allen et al., 2019; Leaché et al., 2017), birds (Fjeldså \& Bowie, 2008), pangolins (Gaubert et al., 2016), and rainforest plants (Born et al., 2011; Budde et al., 2013; Daïnou et al., 2010; Dauby et al., 2010; Duminil et al., 2015; Faye et al., 2016; Gomez et al., 2009; Hardy et al., 2013; Ley et al., 2014, 2016; Lowe et al., 2010). In some cases, divergence patterns match both refugial and riverine predictions (Anthony et al., 2007; Barej et al., 2011; Bohoussou et al., 2015; Gonder et al., 2011; Jacquet et al., 2014; Jongsma et al., 2018; Leaché \& Fujita, 2010; Leaché et al., 2019; Marks, 2010; Portik et al., 2017), suggesting that both may have played roles simultaneously-or in combination-in evolutionary diversification. However, because of the spatial overlap of refugia with montane and riverine systems (Hofer et al., 1999, 2000), and the sparse pollen core and fossil records for the tropics (Colinvaux et al., 1996; Maley \& Brenac, 1998), distinguishing between these three hypotheses has been difficult, especially when relying on phylogeographic data alone.

The three major allopatric diversification hypotheses make the following predictions regarding species diversification patterns in tropical African forests (a) river hypothesis: boundaries between population distributions should correspond to riverine barriers and the ages of populations should be relatively old, corresponding to the ages of the rivers; (b) refuge hypothesis: population distributions should be concordant with locations of hypothesized rainforest refugia during cold, dry periods, and populations are predicted to be relatively young, corresponding to the Pleistocene glaciation cycles; (c) river-refugia hypothesis: population distributions should be correlated with the locations of rainforest refugia and bounded by rivers barriers, or will have been confined to refugial locations and additionally subdivided by rivers. Under this scenario, the timing of population splits should correspond to ages of rivers but would be expected to show patterns of range expansion and contraction for niche model projections to the Pleistocene.
In this study, we use the snake genus Toxicodryas as a model system to test multiple predictions derived from these hypotheses. The genus Toxicodryas consists of two species of large-bodied, rearfanged, venomous sub-Saharan African snakes, T. blandingii, and T. pulverulenta (Figure 2). For most of the 20th century, these taxa were placed in the Asian genus Boiga (Schmidt, 1923), and some authors still classify them as such, but recent phylogenetic analyses recover them as the sister genus to the African egg-eating snakes, Dasypeltis (Pyron et al., 2013; Weinell et al., 2020). No in-depth phylogenetic or phylogeographic analysis has been done within Toxicodryas. Both known species are primarily arboreal, feeding mainly on birds, bats, frogs, and arboreal lizards (Akani et al., 1998; Chippaux \& Jackson, 2019; Nagy et al., 2011; Spawls et al., 2018). Because of their general arboreality, these species are predicted to have distributions strongly correlated with forest and woodland habitats. In addition, Toxicodryas is widely distributed within the Congo Basin and broadly across West and Central Africa, making this genus a suitable system for testing the competing predictions of the river, refugia, and river-refugia hypotheses.

Recent advances in paleo-climate modeling and genome-scale DNA sequencing have opened new avenues to testing classic hypotheses of tropical rainforest speciation (Bell et al., 2017; Leaché et al., 2019; Portik et al., 2017). In this study, we integrate dated phylogeographic inference, population structure analyses, and machine learning-based demographic modeling to identify the timing of divergence as well as the location and permeability of past and present dispersal barriers. These genetic data are combined with paleo-distribution and climate stability modeling to determine the congruence of historical distributions with the refugial and river-refugial hypotheses. Our results demonstrate that, although population distributions alone could be congruent with any of the three hypotheses, diversification times predate the Pleistocene, a finding that aligns with predictions of the river-barrier hypothesis. Moreover, historical demographic analyses support models of no migration among populations since the time of divergence, and no signatures of population bottleneck and subsequent expansion were identified, as predicted under the refuge hypothesis. Additionally, 
species paleo-distribution and climate stability modeling show no suggestion of suitable habitat contraction during or since the Pleistocene. Together, our analyses allow us to reject predictions of refugia hypotheses in favor of the prevailing role of riverine barriers in shaping, structuring, and maintaining diversity in this generally arboreal, forest-associated group of endemic African snakes.

\section{2 | MATERIALS AND METHODS}

\section{1 | Sampling}

We obtained 20 specimens of Toxicodryas (seven T. blandingii and 13 T. pulverulenta) through fieldwork and from various museums (see Table S1). Sampling was representative of the known range of each species throughout the upper and lower Guinean forest blocks of West and Central Africa including the countries of Guinea, Liberia, Ghana, Cameroon, Gabon, and Democratic Republic of the Congo (DRC). Museum catalog numbers, GenBank accession numbers, and locality data for each specimen are presented in Table S1.

\section{2 | Genetic data collection, bioinformatic processing, and locus assembly}

Tissue samples were preserved in 95\% ethanol or RNAlater ${ }^{\mathrm{TM}}$ (SigmaAldrich), and genomic DNA (gDNA) was extracted using the Maxwell RSC system (Promega). The nuclear gene c-mos and the mitochondrial gene cytochrome $b$ (cyt $b$ ) were PCR-amplified for each individual using standard primers (c-mos: S67, S68; Lawson et al., 2005; cyt b: L4910B, H15720; Burbrink et al., 2000) and sequenced on an ABI 3730 capillary electrophoresis system (Applied BioSciences ${ }^{\circledR}$ ). Electropherograms were edited manually in Geneious v5.6.7 (http:// www.geneious.com, Kearse et al., 2012), and resulting sequences were aligned in MAFFT v.5 with default parameters (Katoh \& Kuma, 2002).

We also sequenced genome-wide anonymous nuclear markers for each individual following a modified version of the ddRADseq protocol of Peterson et al., (2012). For each individual, a total of 300-500 ng of gDNA were double digested using the restriction enzymes Sbfl (restriction site 5'-CCTGCAGG-3') and Mspl (restriction site $5^{\prime}-\mathrm{CCGG}-3^{\prime}$ ). The resulting double digestion products were then bead-cleaned with AmpureXP beads (Agencourt) and individually barcoded using custom oligonucleotide adapters. Pooled samples were size-selected to a mean insert length of 541 base pairs (bp) (487-595 bp range) with internal standards with a Pippin Prep ${ }^{\mathrm{TM}}$ (Sage Science, Beverly, MA, USA). Resulting postligation products were amplified for eight cycles with a high-fidelity polymerase (Phusion $^{\mathrm{TM}}$, New England Biolabs). An Agilent TapeStation was used to determine the final fragment size distribution and concentration of each pool. Library pools were combined in equimolar amounts for sequencing on one Illumina HiSeqX lane (with a 10\% PhiX spike-in and 150 bp paired-end reads).
Illumina reads from the ddRAD libraries were processed using STACKS v. 2.4 (Catchen et al., 2013). Because the ddRAD protocol generates strand-specific libraries, prior to read filtering and assembly, we used a read-stitching approach (Hime et al., 2019) to join the first read from an Illumina read pair with the reverse complement of the second, recapitulating the original orientation of fragments in the genome. Stitched reads were quality-filtered and demultiplexed by individual with the process_radtags function in STACKS with the following parameters: demultiplex each library by in-line barcode, check for both restriction enzyme cut sites, remove any read with an uncalled base, rescue barcodes and RAD-Tags, and discard any read with average Phred quality score $<20$ over sliding windows of $15 \%$ of the total read length. Next, we used STACKS to de novo assemble filtered and stitched Illumina read pairs.

We aimed to produce three separate ddRAD data sets, including one for T. blandingii, one for T. pulverulenta, and a combined data set comprising both species. Because the optimal de novo assembly of ddRADseq data can vary widely across taxa (Paris et al., 2017; Shafer et al., 2017), we tested a range of assembly parameters to optimize the recovery of putatively single-copy orthologous loci. Final assembly parameters were selected based on the methods of Paris et al. (2017). According to their recommendations, in USTACKS, we kept $\mathrm{m}$ (the minimum number of reads needed to form a stack) at 3 while in CSTACKS, we varied $M$ (the number of mismatches allowed during loci formation) and $n$ (the number of mismatches allowed during catalog formation) until we identified the parameters at which the maximum number of polymorphic loci were available across $80 \%(r=0.8)$ of the population. For our data, this was found to be $M=5$ and $n=15$. Further parameters were tested in POPULATIONS separately for each species and for the genus as a whole in order to balance missing data and number of polymorphic loci. Within T. blandingii and T. pulverulenta, the percent missing data were low (5\% and $7.3 \%$ missing data, respectively) and no further processing was needed, and $r=0.8$ was used. Because of dissimilarity between the two species causing high levels of missing data in the combined data set, further restrictions were implemented. For the genus-wide data set, we set $r=0.5$ and $p=4$ [p is the minimum number of populations in which a locus must be present (here 4/5)]. This approach increased the number of informative loci, but also the amount of missing data. For each of our three separate data sets, we generated a data set comprising only a single random SNP per locus (for population clustering analyses and demographic modeling), and another data set comprising full-length sequences for all loci (for use in phylogenetic reconstruction).

\section{3 | Phylogenetic analyses}

We concatenated our Sanger data set (c-mos and cyt $b$ ) and implemented bModelTest in Beast v. 2.6.2 to assess all possible substitution models for each gene using a Bayesian approach (Bouckaert \& Drummond, 2017). We conducted a time-calibrated analysis on our partitioned data set in Beast v. 2.6.2 (Bouckaert 
et al., 2019) using a relaxed log-normal clock and a Yule tree prior assuming a constant lineage birth rate. Dating analyses were based on three fossils for calibration in the outgroup, one at the Elapoidea + Colubridae node (minimum age: 30.9 Mya), one at the Heterodon + Farancia node (minimum age: $12.08 \mathrm{Mya}$ ), and one at the Naja + Hemachatus node (minimum age: 17.0 Mya). Fossil ages and placement were based on Head et al. (2016). Two runs of $100,000,000$ generations were conducted and logged every 10,000 generations. Convergence was assessed using Tracer v. 1.7 (Rambaut et al., 2018). A burn-in of $10 \%$ was used to create a maximum clade credibility tree. Node ages are based on median tree heights.

We analyzed our SNP data set, including all samples of both species of Toxicodryas, using both species tree summary quartet and maximum likelihood phylogenetic methods. The quartet method was implemented through SVDquartets (Chifman \& Kubatko, 2014) in PAUP* v. 4.1a166 (Swofford, 2003). We sampled all possible quartets and assessed support using 100 nonparametric bootstraps, and species tree topology was summarized with DendroPy v. 4.4.0 (Sukumaran \& Holder, 2010). We ran a maximum likelihood analysis of our genus-wide SNP data set in IQtree v. 1.6.12 (Nguyen et al., 2014) using 10,000 ultrafast bootstraps (Hoang et al., 2018) and the ModelFinder function to choose the best substitution model (Kalyaanamoorthy et al., 2017). As no outgroups were included in our SNP data set, for both SVDquartets and IQtree the placement of the root of each phylogeny was chosen to match that of the Sanger phylogeny.

\subsection{Assessing genetic structure}

We used multivariate, Bayesian, and admixture-based analyses to assess population structure. In all analyses, clustering algorithms were run on three data sets separately for comparison (T. blandingii, T. pulverulenta, and both species combined [genus Toxicodryas]). A discriminant analysis of principal components (DAPC) was run using Adegenet v. 2.1.1 (Jombart \& Ahmed, 2011). This approach uses discriminant functions to maximize variation among clusters and minimize variation within clusters. The best-clustering scheme was chosen based on Bayesian information criterion (BIC) scores. Numbers of clusters (K) ranging from 1-10 for the genus-level analysis and 1-5 for each species were evaluated and a discriminant function analysis of principal components (DAPC) was performed based on the number of suggested clusters. Ancestry proportions of all individuals were inferred using LEA v. 1.6.0 (Frichot \& François, 2015) through the Bioconductor v. 3.4 package. The sNMF function was used to assess $K$ values from 1-10 for the genus-level analysis and 1-5 for each species with 20 replicates each. Individual admixture coefficients were estimated and the value of $\mathrm{K}$ that minimized cross-entropy was selected (François, 2016; Frichot et al., 2014). Population structure and admixture were also tested using the Bayesian method STRUCTURE v. 2.3.4 (Falush et al., 2003; Pritchard et al., 2000). Each data set was evaluated for $K=1-10$ for the genus-level analysis and 1-5 for each species, with 10 runs per $\mathrm{K}$ and a MCMC burn-in of 10,000 steps followed by 100,000 steps (Porras-Hurtado et al., 2013). Results were evaluated using the Evanno method (Evanno et al., 2005) and plotted through the R package pophelper v. 2.3.0 (Francis, 2017).

\section{5 | Demographic modeling and analysis of gene flow}

To test for historic and recent gene flow between our populations, we used the R package delimitR (Smith \& Carstens, 2020; https:// github.com/meganlsmith/delimitR). This program uses a binned multidimensional folded site frequency spectrum (bSFS; Smith et al., 2017) and a random forest machine learning algorithm to compare speciation models such as no divergence, divergence with and without gene flow, and divergence with secondary contact (Smith \& Carstens, 2020). A bSFS was used because it stores the observed frequencies of the minor alleles for multiple populations and bins them to avoid inference problems associated with sampling too few segregating sites (Smith et al., 2017; Terhorst \& Song, 2015). Demographic histories are simulated using the multi-species coalescent model implemented through fastsimcoal2 (Excoffier et al., 2013) under a user-specified guide tree and set of priors on divergence times, population sizes, and migration rates. The random forest classifier then creates a user-defined number of decision trees from a subset of the prior. Each decision tree compares the empirical bSFS to the SFS of each simulated speciation model and votes for the most similar model. The demographic model with the largest number of votes is chosen as the best model. Out-of-bag error rates are used to assess the power of the random forest classifier. The posterior probability of the selected model is then calculated by regressing against the out-of-bag error rates following Pudlo et al. (2015).

We created folded multidimensional site frequency spectrums for the two T. blandingii clades and the two Central African T. pulverulenta clades using easySFS (https://github.com/isaacovercast/ easySFS), a wrapper for dadi (Gutenkunst et al., 2009). The West African T. pulverulenta clade was not included because of the low sample size available for this lineage. We simulated 100,000 data sets under four models: no divergence (Model 1), divergence without gene flow (Model 2), divergence with secondary contact (Model 3), and divergence with gene flow (Model 4). Priors for both models were drawn from uniform distributions for population size: 10,000$1,000,000$ haploid individuals (twice the number of estimated diploid individuals), divergence time: 20,000-2,000,000 generations, migration rate: $0.000005-0.005$ corresponding to $0.05-5$ migrants per generation. We then coarsened our empirical site frequency spectra to 10 bins each. Our out-of-bag error rates were calculated, and 500 random forest classifiers were simulated using 100,000 pseudo-observed data sets for each model. A confusion matrix was calculated to determine how often the correct model was selected and posterior probability for the "best" model was estimated for each species. 
The R package rangeExpansion (Peter \& Slatkin, 2013, 2015) was used to assess signatures of population size change in the two $T$. blandingii clades and the two Central African T. pulverulenta clades. The West African T. pulverulenta clade was excluded because of its small sample size. This program implements a founder effect algorithm using a steppingstone model, assuming that each colonizing event is associated with a founder event, to determine whether a population shows signatures of expansion or equilibrium isolationby-distance (Peter \& Slatkin, 2013, 2015). If population expansion is identified, the program will infer the strength of the founder effect and the most likely expansion origin (Peter \& Slatkin, 2013, 2015).

\section{6 | Species delimitation}

We conducted a species delimitation analysis on our Sanger data set using a Bayesian approach through BPP v.4.2.9 (Flouri et al., 2018; Yang, 2015) and a user-specified guide tree (Rannala \& Yang, 2013; Yang \& Rannala, 2010). Following Yang and Flouri (2020), we used the default prior for theta $(\theta=0.002)$ and calculated the tau prior based on the estimated divergence times $(\tau=0.036)$. We used a burn-in of 20,000 , a sampling size of 200,000 , and a sampling frequency of two. The analysis was run twice with a random seed to ensure consistency.

Additionally, the package DelimitR (Smith \& Carstens, 2020; https:// github.com/meganlsmith/delimitR) was used to conduct a species delimitation analysis on our ddRAD data set. As described above for the demographic analysis, this program uses a binned multidimensional folded site frequency spectrum (bSFS; Smith et al., 2017) and a random forest machine learning algorithm to compare the speciation models: no divergence, divergence with gene flow, divergence with secondary contact, and divergence without gene flow (Smith \& Carstens, 2020). Each scenario is simulated using a multi-species coalescent model implemented through fastsimcoal2 (Excoffier et al., 2013) and userspecified priors on divergence times, population sizes, and migration rates. The empirical bSFS to the SFS of each simulated speciation model is then compared by the random forest classifier and posterior probabilities, and out-of-bag error rates are calculated.

\section{7 | Species distribution modeling}

Occurrence data for each species were obtained from the specimens used in this study, "expert" identified individual occurrences from the Global Biodiversity Information Facility (GBIF), and researchgrade locality records from iNaturalist (www.inaturalist.org) that could be visually identified by the authors. Duplicate records were removed, and points were thinned within a distance of 10 kilometers using the spThin package (Aiello-Lammens et al., 2015) in R v. 3.4.4 (R Core Team, 2019). This resulted in a total of 43 T. blandingii localities and 30 T. pulverulenta localities (Figure S1). A subset of points from each data set was set aside for model calibration (75\%) and internal testing (25\%) following Cobos et al. (2019).
Environmental data were obtained from the WorldClim database v. 1.4 (Hijmans et al., 2005). Fifteen of the 19 bioclim variables were downloaded at a 2.5-min resolution. We excluded bio8 (Mean Temperature of Wettest Quarter), bio9 (Mean Temperature of Driest Quarter), bio18 (Precipitation of Warmest Quarter), and bio19 (Precipitation of Coldest Quarter) which, as combinations of other variables, are known to create artifacts in distribution models (Escobar et al., 2014). The same 15 variables were used for the Last Glacial Maximum (LGM) under three general circulation models (GCMs): CCSM4, MIROC-ESM, and MPI-ESM-P. In order to reduce spatial autocorrelation, principal component analyses (PCAs) were performed on present bioclim variables and projected to the LGM for the extent of sub-Saharan Africa.

Model calibration areas were defined as a 1,000-km buffer around occurrence points for each species. Model calibration, creation, projection, and evaluation were done using the R package kuenm (Cobos et al., 2019). In order to calibrate our models, we created 1,479 candidate models for each species by combining three sets of environmental predictors (PCAs 1-6, 1-5, 1-4), 17 possible regularization multipliers (0.1-1.0 at intervals of 0.1, 2-6 at intervals of 1 , and 8 and 10), and all combinations of five feature classes (linear $=\mathrm{l}$, quadratic $=\mathrm{q}$, prod$\mathrm{uct}=\mathrm{p}$, threshold $=\mathrm{t}$, and hinge $=\mathrm{h}$; Cobos et al., 2019).

Candidate models were run in Maxent (Phillips et al., 2006) and chosen based on significant partial receiver operating characteristic (ROC) scores (Peterson et al., 2008), omission rates of $E \leq 5 \%$ (Anderson et al., 2003), and corrected Akaike Information Criterion AICc $\leq 2$ to minimize model complexity (Warren \& Seifert, 2011). These models determined the parameter set used for final model creation.

Final models were created for each species using the full set of occurrence records and the parameters chosen during model calibration. Models were run in Maxent with ten bootstrap replicates and logistic outputs. After models were run in the present, they were projected to the LGM and mid-Holocene for the three GCMs. The mobility-oriented parity (MOP) index was used to test for model extrapolation (Soberón \& Peterson, 2005). Models were visualized in QGIS 3.4 and thresholded to $5 \%$ to create presence-absence maps. Models from each time period were summed to estimate potential LGM and mid-Holocene distributions as well as continuous stability maps (Devitt et al., 2013; Yannic et al., 2014).

\section{3 | RESULTS}

\subsection{Genetic data collection, bioinformatic processing, and locus assembly}

Our concatenated c-mos and cyt b data set (Sanger data set hereafter) consisted of $1,237 \mathrm{bp}$, including indels. Both genes were represented in all samples with the exception of c-mos for the outgroup Contia longicaudae. Information on samples used in the Sanger analysis, including museum catalog number and GenBank accession number, can be found in the Supporting Information. After filtering (see Section 2, above), our genus-level ddRAD data set consisted of 
2,848 loci with $20.7 \%$ missing data (here defined as proportion of missing loci across all individuals), and an effective mean per-sample depth of coverage of $78.7 x \pm 13.6 x$. Our T. blandingii data set consisted of 7,231 loci with $5.0 \%$ missing data, and an effective mean per-sample depth of coverage of $83.6 x \pm 12.0 x$. Our T. pulverulenta data set consisted of 4,471 loci with $7.3 \%$ missing data, and an effective per-sample mean depth of coverage of $77.9 x \pm 14.6 x$. The concatenated ddRAD data set used for phylogenetic analyses had a length of 450,512 bp and 3,024 SNPs.

\section{2 | Phylogenetic structure and divergence dating}

Broad-scale phylogenetic relationships estimated in analyses of our Sanger and SNP data sets were identical in topology, with strongly supported internal nodes throughout (Figure 3; Figure S2). Our twolocus Sanger tree and our 2,848-locus ddRAD SNP trees both supported two divergent lineages of $T$. blandingii, in West and Central Africa, respectively, and three divergent lineages of T. pulverulenta, one from West Africa and two in Central Africa, north and south of the Congo River (Figure 3). Fossil-calibrated divergence dating suggests that $T$. blandingii and T. pulverulenta diverged in the midMiocene (median age 12.2 Mya). Diversification within each species is estimated to have taken place primarily in the Pliocene, with the two clades in T. blandingii diverging around 4.3 Mya, the West African clade of T. pulverulenta diverging around 3.3 Mya, and the two Central African clades diverging around 1.9 Mya (Figure 3).

\section{3 | Population structure}

A comparison of BIC values from the genus-level DAPC analyses suggested a total of five genetic clusters, with two populations in T. blandingii and three in T. pulverulenta, matching the clades identified in the phylogenetic analyses (Figure S3). Our admixture-based method, LEA, identified two distinct genetic clusters at the genus level, corresponding to the two Toxicodryas species, and the same two populations for T. blandingii and three populations for T. pulverulenta as suggested by DAPC (Figure 4). A low amount of admixture was identified in the Cameroonian sample of $T$. blandingii, and varying levels of admixture were suggested for the Gabonese samples of T. pulverulenta (Figure 4). The population assignment of individuals between the two clustering methods was identical; however, admixture between populations was not detected by DAPC. Similarly, STRUCTURE suggested two populations at the genus level, and two in T. blandingii, but combined the Central African clades and suggested two populations, instead of three, for T. pulverulenta. Three populations were supported as the second highest $\Delta K$ and showed identical admixture proportions to those from LEA. We used five populations for our remaining analyses because multivariate-based analyses such as LEA and DAPC do not make assumptions about Hardy-Weinberg equilibrium and may be preferable over Bayesian methods such as STRUCTURE when sample sizes are small or uneven (Puechmaille, 2016).

\subsection{Demographic modeling and analysis of gene flow}

Using machine learning-based demographic model selection, we identified divergence without gene flow as the best model for $T$. blandingii with a posterior probability of 0.68 , and divergence with gene flow for $T$. pulverulenta with a posterior probability of 0.63 (Figure 5). For both species, models representing no divergence and divergence with secondary contact received very low support (Tables S2 and S3). The out-of-bag error rate for T. blandingii was $17.3 \%$ and for T. pulverulenta was $22.8 \%$, with all of the misclassifications being between highly similar models (i.e., between divergence with or without gene flow, as opposed to between divergence and no divergence). While it is possible that small sample sizes for several of our populations may have negatively impacted the power of our demographic analyses, our values for posterior probability and out-of-bag error rate are similar to those obtained by Smith and Carstens (2020), suggesting that the impact was minimal. The confusion matrix and number of votes per model can be found in Tables S2 and S3.

Population size analyses for demographic signatures of range expansion versus equilibrium isolation-by-distance strongly rejected the expansion model for each of the four populations tested (West African T. blandingii: $p=6.38$; Central African T. blandingii: $p=28.01$; Gabon T. pulverulenta: $p=833.43$; Congo Basin T. pulverulenta: $p=0.10$ ). Accordingly, the strength of the founder effect (q) for each population was generally small, and the founder distance (d) was large (West African T. blandingii: $q=0.000037, d=137.46$; Central African T. blandingii: $\mathrm{q}=0.000028, \mathrm{~d}=180.61$; Gabon $T$. pulverulenta: $\mathrm{q}=0.000042, \mathrm{~d}=120.65$; Congo Basin T. pulverulenta: $q=0.00017, d=29.35$.

\section{5 | Species delimitation}

We tested five distinct clades of Toxicodryas: West African T. blandingii, Central African T. blandingii, West African T. pulverulenta, and two Central African clades of T. pulverulenta using the Bayesian species delimitation method BPP v. 4.2 (Flouri et al., 2018; Yang, 2015). Our analysis supported all five clades of Toxicodryas as distinct species with high posterior probability $(\mathrm{pp}=0.98)$. Our analysis was run twice with random seeds to check for consistency, and both runs gave highly similar results. Similarly, DelimitR identified divergence without gene flow as the best model for T. blandingii and divergence with gene flow for T. pulverulenta. For both species, models suggesting lack of divergence or present-day gene flow had very low probabilities (Tables S2 and S3).

\section{6 | Distribution modeling}

Species distribution modeling suggested widely overlapping ranges for T. blandingii and T. pulverulenta, with both species documented 

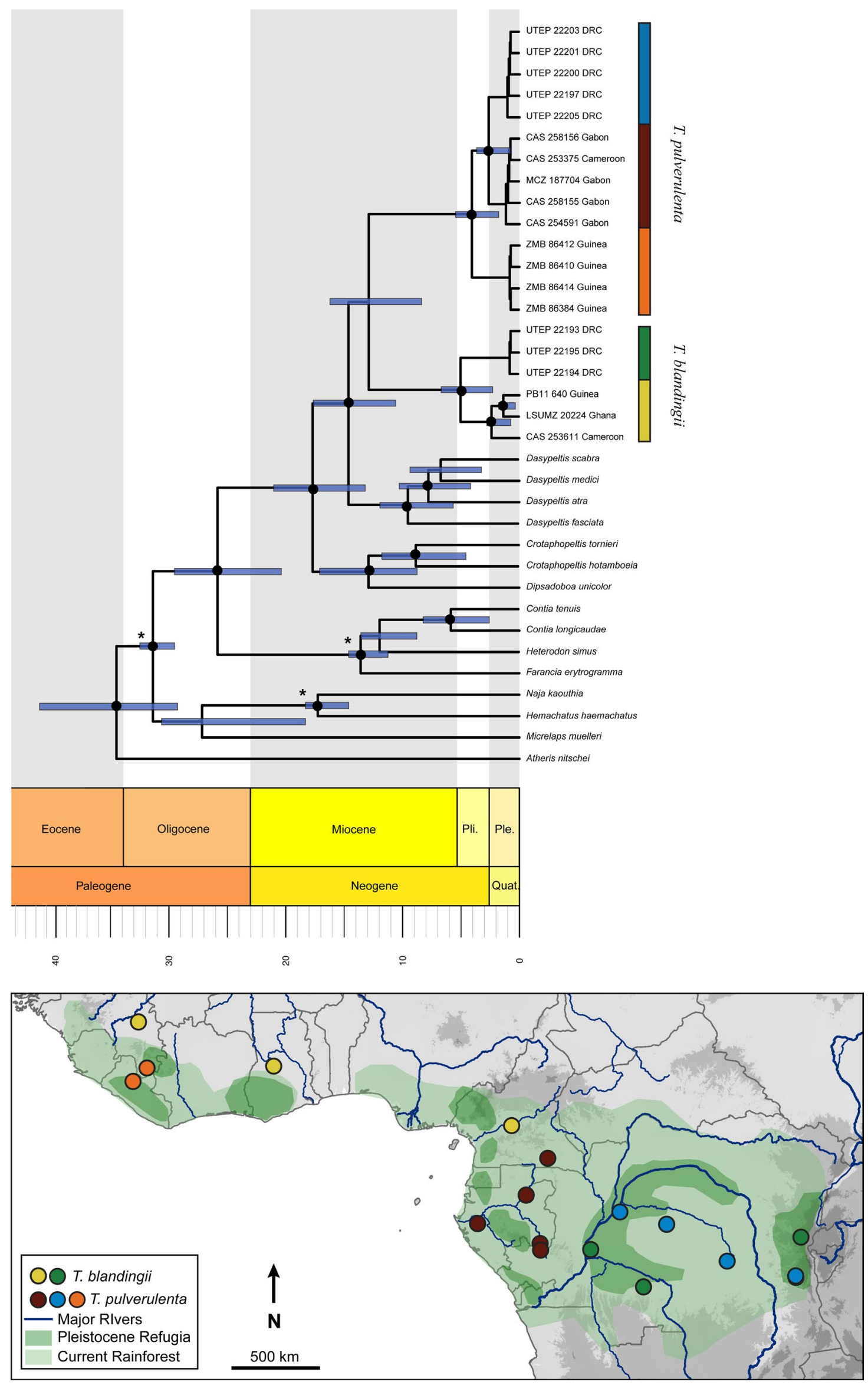
FIGURE 3 Top: A time-calibrated Bayesian phylogeny for Toxicodryas with c-mos and cyt $b$ genes. Highly supported nodes (PP $\geq 0.9$ ) are denoted with a black circle. Fossil-calibrated nodes are denoted with an asterisk. Node bars represent $95 \%$ confidence intervals. RADseq phylogenies showed identical topologies. Bottom: Toxicodryas clade distributions overlaid onto a map of elevation, major rivers and hypothesized rainforest refugia

FIGURE 4 Population structure of the genus Toxicodryas. Top: Bar plot of population structure and membership probabilities for $\mathrm{K}=5$ analyzed in LEA. Bottom: Geographic representation of population structure for $\mathrm{K}=5$ overlaid onto a map of major rivers
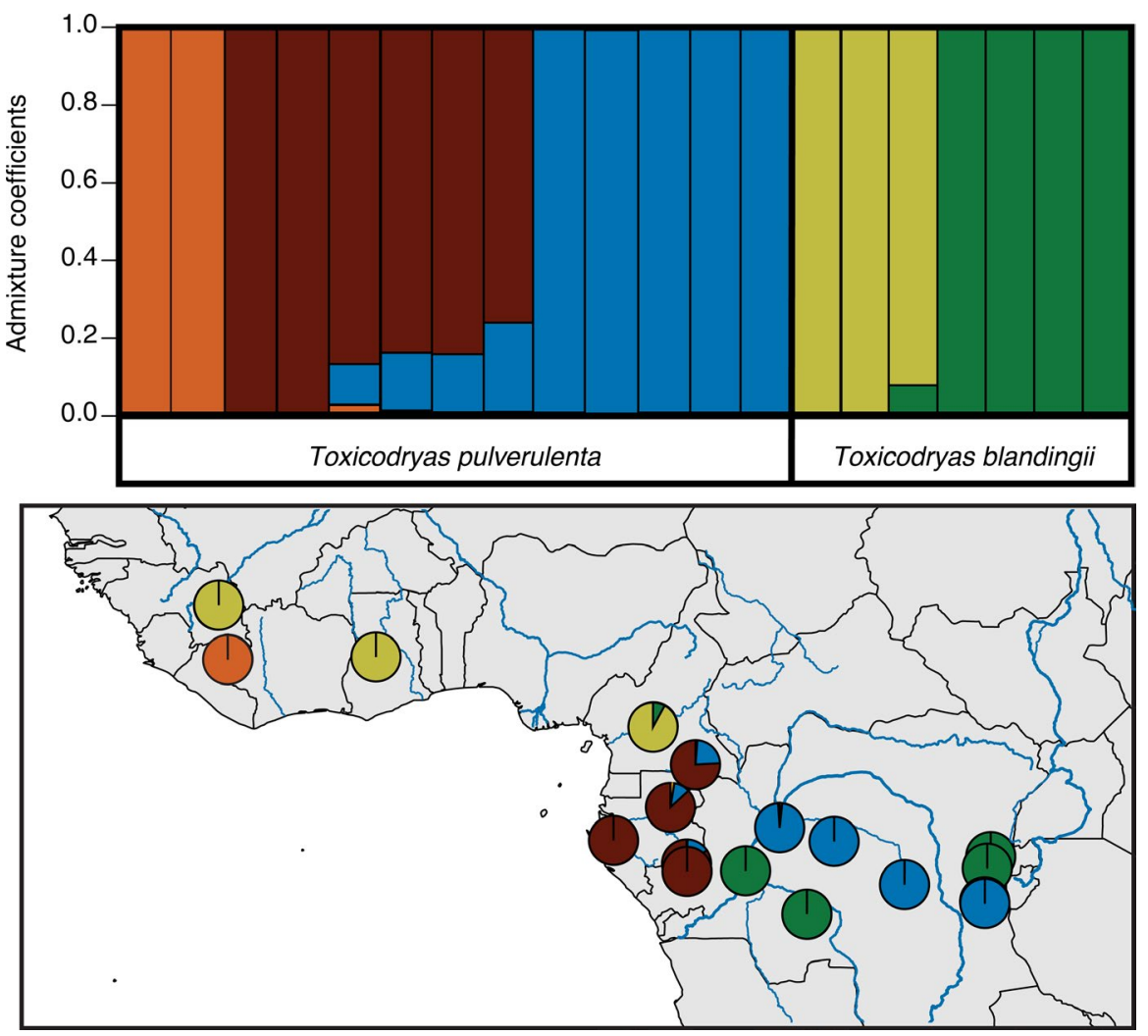

from both rainforest and woodland habitats (Figure 6). Paleodistribution models for the LGM suggested a slight northern and southern contraction of suitable habitat for the genus in West and Central Africa. Toxicodryas pulverulenta showed evidence of a slight southward range expansion into Angola, while the range of T. blandingii remained stable (Figure 6a). The mid-Holocene distribution was highly similar to the present-day distribution for all data sets (Figure 6b).

Continuous climate stability maps estimating the areas of persistent suitable habitat from the LGM to the present suggest that the core distribution of each species has remained stable through time (Figure 6c). Instability in suitable habitat is only found on the edges of the species range, with the greatest potential for distribution change in southern Central Africa. No northward range expansion past the present day was estimated at any time scale in Central Africa, but lesser degrees of northward expansion may have been possible in West Africa.

\section{4 | DISCUSSION}

The relative roles of rivers and refugia in shaping the high levels of species diversity in tropical rainforests have been widely debated for decades (e.g., Amorim, 1991; Colinvaux et al., 2001; DeMenocal, 2004; Haffer, 1969, 1997; Mayr \& O'Hara, 1986; Vitorino et al., 2016; reviewed in Couvreur et al., 2021). Only recently has it become possible to take an integrative approach to answering these questions with genomic sequencing and paleo-species distribution modeling (Leaché et al., 2019; Portik et al., 2017). Herein, we tested alternate predictions of the classic river, refuge, and riverrefuge hypotheses for terrestrial faunal diversification using a novel study system: the arboreal African snake genus Toxicodryas. We found strong support for predictions derived from the river hypothesis over the refuge and river-refuge hypotheses, based on the ages, locations, and timing of gene flow between each of our populations, as well as a lack of support for suitable habitat and population size contraction during the last glacial maximum.

\section{1 | Species diversification}

This study represents the first phylogenetic analysis of the genus Toxicodryas. Phylogenetic analyses of our two-locus Sanger data set and 2,848-locus RADseq SNP data set reveal two deeply divergent, strongly supported lineages in T. blandingii and three in T. pulverulenta (Figure 3; Figure S2). Although the two recognized species 


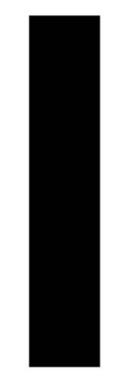

Model 1

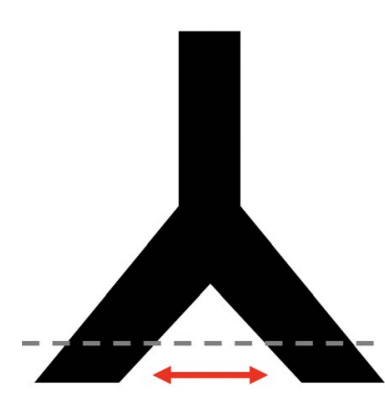

Model 3
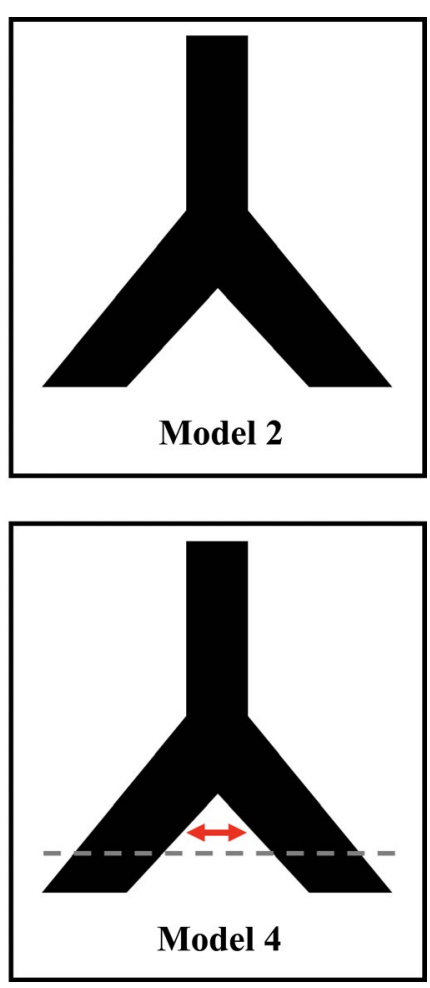

FIGURE 5 Four demographic models tested using DelimitR. Model 1: no divergence, Model 2: divergence without gene flow, Model 3: divergence with secondary contact, and Model 4: divergence with gene flow. Model 2 was chosen for Toxicodryas blandingii, and Model 4 was chosen for the two Central African clades of T. pulverulenta

are broadly sympatric, clades within each species are generally situated allopatrically across river barriers. Of the three T. pulverulenta clades, one is distributed in West Africa (albeit with limited sampling) and two are distributed in Central Africa, separated by the western Congo River. The boundary between the two clades within T. blandingii is delimited somewhere between the Sanaga River in Cameroon and the Congo River in the DRC, and, while the species distribution reaches this area, no genetic sampling is available. Both rivers have frequently been interpreted as population barriers in other terrestrial vertebrates (Blackburn, 2008; Jongsma et al., 2018; Leaché \& Fujita, 2010; Leaché et al., 2019; Portik et al., 2017), and a recent analysis of morphological data by Greenbaum et al. (in press) of all available Toxicodryas material, including voucher specimens of the genetic samples used herein, has identified the most likely biogeographic barriers within the genus to be the confluence of the Congo and Ubangi Rivers for the Central African populations of T. blandingii and T. pulverulenta, and the Niger Delta as the barrier for the West and Central African populations of T. pulverulenta.

Our population structure analyses are concordant with phylogenetic analyses supporting five distinct genetic clusters (Figure 4), and our species delimitation analyses suggest that all of these clusters represent distinct, independently evolving lineages. Minor levels of admixture seem to have occurred between the T. pulverulenta clades separated by the western Congo River, and between the two clades of T. blandingii in the sample collected at the Sanaga River (Figure 4); however, our demographic analyses do not support contemporary gene flow, suggesting that this admixture is a result of historic introgression or incomplete lineage sorting. In both species, the Congo River barrier seems to be stronger in the west where the river is wider, and the current is stronger. In eastern DRC, samples of clades from both species can be found on either side of this river (Figure 4).

\subsection{Divergence time estimates}

Divergence time estimates from a time-calibrated phylogeny also support predictions derived from the river-barrier hypothesis. Toxicodryas blandingii and T. pulverulenta diverged in the midMiocene, and subsequent intraspecific diversification took place in the Pliocene (Figure 3). If the Pleistocene rainforest refugia hypothesis was supported, we would expect diversification times dating to the Pleistocene glaciation cycles, $<2.5$ million years ago. Similar mid-Miocene and Pliocene divergence times have been noted for other widespread Central and West African taxa including frogs (Bell et al., 2017; Jongsma et al., 2018; Zimkus et al., 2017), and terrestrial snakes (Portillo et al., 2019), and similar West to Central African distribution splits have been seen in forest cobras (Wüster et al., 2018), frogs (Leaché et al., 2019), lizards (Allen et al., 2019), and shrews (Jacquet et al., 2015).

Greenbaum et al. (in press) identified two major river systems, the Congo/Ubangi and the Niger Delta, as likely barriers between Toxicodryas clades based on a combined molecular and morphological analysis of the genus. The Congo River and the Ubangi River, one of the Congo's tributaries, date back to the mid-late Miocene (Flügel et al., 2015; Stankiewicz \& de Wit, 2006). The Congo is one of the largest rivers in the world, second only to the Amazon in discharge volume, and first in the world for depth. Much of its length, especially in the lower Congo, is characterized by swift-flowing currents and waterfalls. The depth and intensity of this river have rendered it a well-known barrier to many species including primates (Harcourt \& Wood, 2012; Mitchell et al., 2015; Takemoto et al., 2015; Telfer et al., 2003), shrews (Jacquet et al., 2015), and other snakes (Portillo et al., 2019). The Niger is the third largest river in Africa and it likely originated approximately 29-34 million years ago (Chardon et al., 2016; Reijers, 2011), reaching its full extent by the mid-Miocene as continental uplift progressed (Reijers, 2011). It is a biogeographic barrier for several species of frogs (Onadeko \& Rödel, 2009; Rödel et al., 2014), primates (Eriksson et al., 2004), and shrews (Igbokwe et al., 2019).

\section{3 | Alternate biogeographic barriers}

While the timing and locations of population divergences in this study correspond with river barriers, the Miocene was also a time of 
(a)

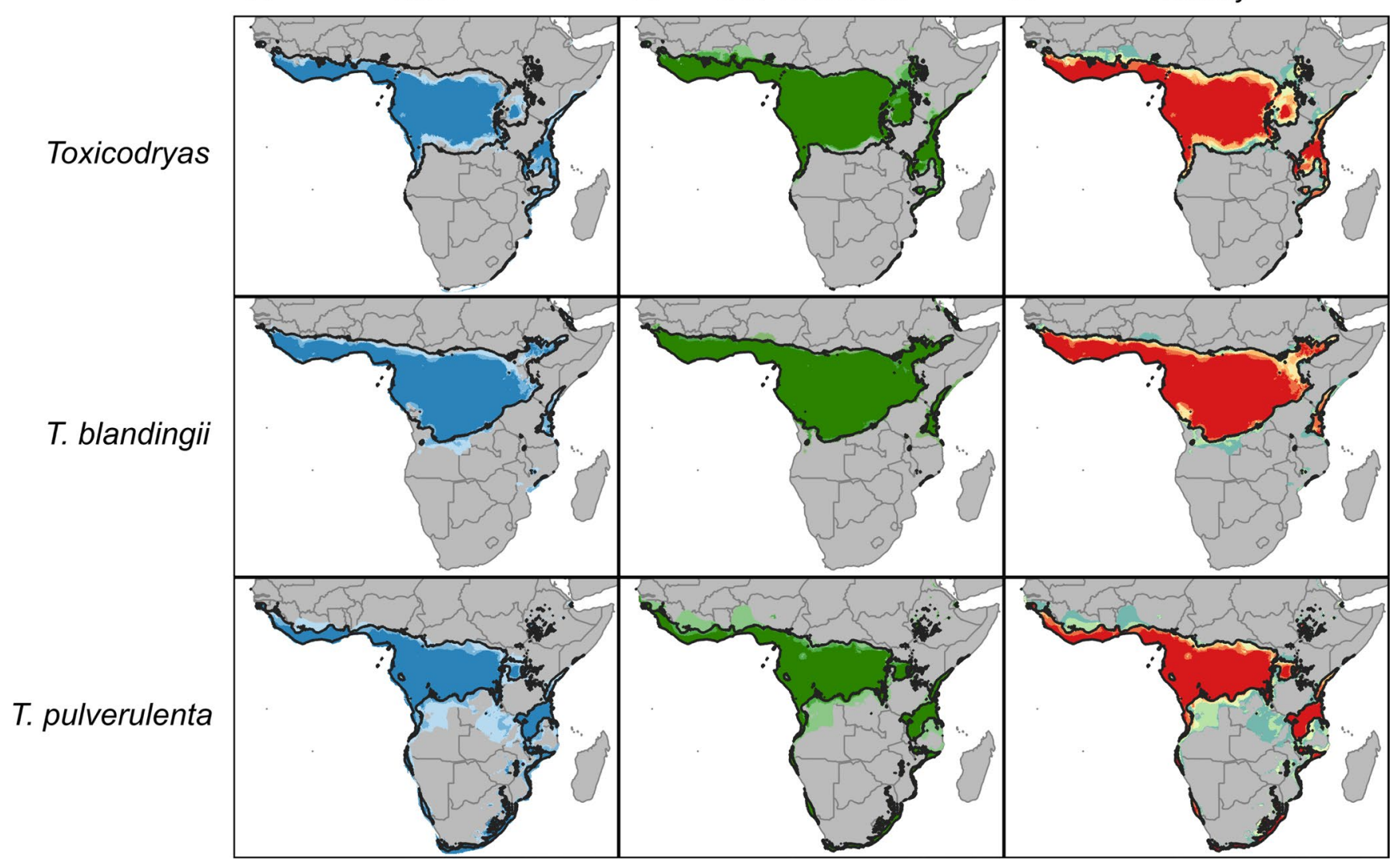

(b) Mid-Holocene (c)
Stability

FIGURE 6 Paleo-distribution models showing (a) the suitable habitat for Toxicodryas during the last glacial maximum (LGM). The shade of blue represents agreement between global climate models (GCMs) with the darkest blue indicating agreement between all three GCMs and the lightest blue indicating support from only one GCM. (b) The suitable habitat for Toxicodryas during the mid-Holocene. The shade of green represents agreement between GCMs with the darkest green indicating agreement between all three GCMs and the lightest green indicating support from only one GCM. (c) The stability of suitable habitat across the LGM, mid-Holocene, and present, with red indicating high stability and blue indicating low stability

global climatic change characterized by dramatic cooling and vegetation shifts throughout sub-Saharan Africa (Couvreur et al., 2021; Herbert et al., 2016; Jacobs, 2004; Menegon et al., 2014). Although most research surrounding the role of refugia in driving diversification has focused on the dramatic climate oscillations of the Pleistocene, it is likely that refugia are able to form during any period of climatic change (Haffer, 1997; Hampe \& Jump, 2011; Jansson \& Dynesius, 2002), but the role of possibly older refugia has received little attention in the literature (Couvreur et al., 2021; Hampe \& Jump, 2011).

It is interesting to note that a number of biogeographic barriers that often play a role in species diversification in Central Africa do not appear to influence the genetic patterns seen in Toxicodryas. One of these biogeographic barriers is the Dahomey Gap, a dry forest-savanna mosaic that separates the Upper and Lower Guinean forest blocks (Figure 1). Based on pollen cores and climatic modeling, the Dahomey Gap has existed in some form for at least the last 150,000 years (Allen et al., 2020; Dupont \& Weinelt, 1996) and has played a variable role in species diversification in West Africa (Droissart et al., 2018; Leaché et al.,
2020; Linder et al., 2012; Nicolas et al., 2010; Penner et al., 2011; White, 1979). The West African clade of T. blandingii crosses the Dahomey Gap and our species distribution analyses suggest that conditions are suitable for both species in that area, likely as a result of the forest-mosaic providing suitable habitat (Chippaux \& Jackson, 2019).

In addition, the two mountain ranges that bisect both species of Toxicodryas' ranges, the Cameroon Volcanic Line and the Albertine Rift, do not appear to impact the genetic structure of these species. Both mountain ranges originated approximately 30 million years ago with major geological developments occurring within the Miocene (Burke, 2001; Macgregor, 2015; Marzoli et al., 2000; Paul et al., 2014; Reusch et al., 2010) and both are continuing to undergo uplift and volcanism. Both are also biogeographically important in Central Africa as proposed Pleistocene refugia (Maley, 1996; Figure 1, refugia 4 and 10) and as barriers to dispersal for a variety of herpetofaunal species (e.g., Evans et al., 2011; Greenbaum et al., 2015; Menegon et al., 2014; Wüster et al., 2018; Zimkus \& Gvoždík, 2013). However, they seem to have played neither role in the evolution of the genus Toxicodryas. 


\section{4 | Population demography}

We used machine learning-based demographic model selection to test different gene flow scenarios between the populations in each of our two species. If river formation was the major driver of diversification in these species, we might expect to see divergence with low or no gene flow at the time of divergence as the river was forming (Figure 5: models 2 and 4), but we would be less likely to see recent gene flow. Alternatively, we might be more likely to observe recent gene flow if the Pleistocene refugia hypothesis was supported, as populations diverge and reunite during glaciation cycles (Smith \& Carstens, 2020; Figure 5: model 3). Our demographic analyses in dicate divergence without gene flow between the two T. blandingii clades and divergence with minor gene flow across the Congo River in the two Central African T. pulverulenta clades (Figure 5). Recent gene flow was ruled out with high confidence in both species (Table S3), further supporting the river hypothesis over the refuge hypothesis. In addition, population expansion analyses found none of the signatures of population bottleneck with subsequent expansion that would be expected under the refuge hypothesis, and strongly rejected this hypothesis in favor of equilibrium isolation-bydistance in all of our populations.

In light of the Miocene/Pliocene divergence times and lack of gene flow between these five clades, it is likely that they represent distinct evolutionary lineages. Based on these molecular results, significant differences in scale counts, and even venom toxicity, the Central African populations of T. blandingii (east of the Congo/ Ubangi Rivers) and T. pulverulenta (east of the Niger Delta) represent cryptic new species that are in the process of being formally described (Greenbaum et al. in press). The two Central African clades of T. pulverulenta, separated by the Congo River will be conservatively described as one species based on the results of our STRUCTURE v. 2.3.4 analysis (Falush et al., 2003; Pritchard et al., 2000).

\subsection{Paleo-distributions and habitat stability}

The nature of the intervening habitat surrounding rainforest refugia during the Pleistocene has been widely debated (reviewed in Couvreur et al., 2021). Some authors have argued that much of the Central African rainforest was replaced by savannas (DeMenocal, 2004; Maley, 1996; Maley \& Brenac, 1998), whereas others have emphasized the possibility of more subtle shifts in forest composition (i.e., from wet to dry forest; Colinvaux et al., 1996, 2001; White, 1981). A shift from rainforest to warm temperate woodland and temperate broadleaf evergreen forest, as opposed to savannas, during the last glacial maximum was strongly supported by recent, comprehensive global vegetation models (Allen et al., 2020).

Toxicodryas species are generally characterized as arboreal across rainforest and woodland habitats and the two species exhibit widely overlapping distributions in West and Central Africa (Chippaux \& Jackson, 2019). Our paleo-distribution modeling suggested that no substantial contraction of suitable climate occurred for either species during the LGM (Figure 6a), and our habitat stability mapping suggested that core ranges of both species have remained stable for the past 22,000 years (Figure 6c). The greatest potential for habitat expansion in this species appears to be to the south into northern Angola and southern DRC (Figure 6).

Similar paleo-distribution studies on frogs have suggested substantial habitat contraction in Central Africa during the Pleistocene (Leaché et al., 2019; Portik et al., 2017). In contrast, our inferred widespread habitat stability in Toxicodryas may be a result of the relatively reduced dependence of arboreal snakes on moist habitats, as reflected by their distribution in both woodland and rainforest. The stability of Toxicodryas habitat through the Pleistocene supports the hypothesis that rainforest composition shifted to dryer woodlands surrounding rainforest refugia, instead of a more dramatic shift to strict savanna habitat. Southward shifts in species suitability may correspond with predicted forest distribution shifts of White (1981) and Allen et al. (2020), suggesting a replacement of lowland rainforest with cooler, more temperate forest.

\section{5 | CONCLUSION}

The complexity of geographic barriers in West and Central Africa, and the association of refugia with areas of high surface relief or riparian zones (Hofer et al., 1999, 2000; Figure 1), makes it extremely difficult to untangle the relative importance of different diversification mechanisms with distribution data alone (Leaché et al., 2019; Portik et al., 2017). This difficulty is particularly salient in our study system, where distribution data could suggest the association of populations with hypothesized refugia around the Congo River, Gabon, and in West Africa (refugia 9, 5-8, and 1-3, respectively, Figures 1 and 3). Yet, our dated phylogenies and paleo-distribution models reject the Pleistocene population age and habitat contraction predictions of the refugial hypotheses in favor of the river-barrier hypothesis.

It is important to note, however, that as a result of the difficulty in finding and obtaining tissues from arboreal, venomous, Central African snakes, the small sample sizes used in this analysis may have influenced the inference of our population demographic parameters (Hale et al., 2012; Nelson et al., 2012; Subramanian, 2016; Zwickl \& Hillis, 2002). These impacts would have most likely led to an underestimation of the effects of more recent events in the population's history by missing alleles present at low frequencies (Hale et al., 2012; Nelson et al., 2012; Subramanian, 2016). While similar sample sizes have been used in phylogenomic studies of other difficult-to-find or difficult-to-sample organisms (e.g., Frugone et al., 2019; Muniz et al., 2018; Nash et al., 2018), and simulation studies on empirical data have suggested that small sample sizes (as small as three to four samples per population) can give accurate results if the number of SNPs in the data set is large (Jeffries et al., 2016; Landguth et al., 2012; Nazareno et al., 2017; Qu et al., 2020), more dense sampling of the genus Toxicodryas from throughout their range would be ideal for fully understanding the demographic history of these species. 
These results highlight the importance of using an integrative, multidisciplinary approach to statistically distinguish among competing hypotheses to explain high levels of geographically concentrated species biodiversity. Moving beyond pure pattern-based inference, a deeper and more nuanced understanding of the production, partitioning, and maintenance of diversity in complex landscapes may lead to inference of environmental and evolutionary processes that accumulate terrestrial biodiversity in tropical areas, which coincide in many cases with Global Biodiversity Conservation Hotspots (Hrdina \& Romportl, 2017; Mittermeier et al., 2000, 2011; Myers, 1988) and other imperiled ecosystems on Earth.

\section{ACKNOWLEDGMENTS}

We would like to thank the University of Kansas Biodiversity Institute and the Office of Graduate Studies for funding associated with ddRAD sequencing, and Marlon Cobos for advice regarding niche modeling. We are grateful to all of the people and institutions that lent tissues and extractions for this study, including Lauren Scheinberg at California Academy of Sciences, Seth Parker at Louisiana State University Museum of Natural Science, Breda Zimkus at Museum of Comparative Zoology (Harvard University), and Addison Wynn at United States National Museum of Natural History. The Brown Lab was supported by the National Science Foundation (DEB 1654388 and 1557053) during the course of genomic data collection at KU. Partial funding for Illumina sequencing in this study came from the Docking Faculty Scholar Fund of the College of Liberal Arts and Sciences and the Biodiversity Institute of the University of Kansas. We thank Konrad Mebert for providing life photographs of both Toxicodryas species from Democratic Republic of Congo. EG and CK thank their field companions W.M. Muninga, M.M. Aristote, M. Zigabe, A.M. Marcel, M. Luhumyo, J. and F. Akuku, F.I. Alonda, and the late A. M'Mema. The Centre de Recherche en Sciences Naturelles and Institut Congolais pour la Conservation de la Nature provided project support and permits. EG was supported by the Percy Sladen Memorial Fund, an IUCN/ SSC Amphibian Specialist Group Seed Grant, K. Reed, research funds from the Department of Biology at Villanova University, two National Geographic Research and Exploration Grants (nos. 8556-08 and WWR018-17), the University of Texas at El Paso, and the US National Science Foundation (DEB-1145459). PMH thanks the KU Biodiversity Institute for postdoctoral fellowship support. MOR received funding from the German Research Foundation (DFG VE 183/4-1 \& RO 3064/1-2) and the Federal Ministry of Education and Research (BMBFProject W08 BIOTA-West, 01LC0017). JP is thankful to Michael Barej as well as to numerous people for assistance with field work as well as the Guinean authorities for all necessary permits.

\section{CONFLICTS OF INTEREST}

None declared.

\section{AUTHORS' CONTRIBUTIONS}

K.E.A., A.T.P., and R.M.B. designed the study. E.G., C.K., M.-O. R, and J.P. provided tissues. K.E.A., P.M.H. and V.V.S. performed the laboratory work. K.E.A., P.M.H and W.P.T.N analyzed the data. K.E.A wrote the manuscript. E.G., P.M.H., J.P., M.-O. R and R.M.B. edited the manuscript.

\section{DATA AVAILABILITY STATEMENT}

DNA sequences of c-mos and cyt $b$ are accessioned on GenBank (accession numbers: MW655833-MW655873). Data from ddRAD processing, bioclimatic data, and Maxent input files will be re-archived in the Open Science Framework Digital Repository at https://doi. org/10.17605/OSF.IO/8EC39

\section{ORCID}

Kaitlin E. Allen (iD https://orcid.org/0000-0002-0894-4036

\section{REFERENCES}

Aiello-Lammens, M. E., Boria, R. A., Radosavljevic, A., Vilela, B., \& Anderson, R. P. (2015). spThin: An R package for spatial thinning of species occurrence records for use in ecological niche models. Ecography, 38, 541-545. https://doi.org/10.1111/ecog.01132

Akani, G. C., Barieenee, I. F., \& Luiselli, L. (1998). Observations on habitat, reproduction and feeding of Boiga blandingii (Colubridae) in southeastern Nigeria. Amphibia-Reptilia, 19, 430-436.

Allen, J. R., Forrest, M., Hickler, T., Singarayer, J. S., Valdes, P. J., \& Huntley, B. (2020). Global vegetation patterns of the past 140,000 years. Journal of Biogeography, 47, 2073-2090. https://doi.org/10.1111/ jbi.13930

Allen, K. E., Tapondjou Nkonmeneck, W. P., Greenbaum, E., Welton, L. J., $\&$ Bauer, A. M. (2019). High levels of hidden phylogenetic structure within Central and West African Trachylepis skinks. Salamandra, 55, 231-234.

Amorim, D. D. S. (1991). Refuge model simulations: Testing the theory. Revista Brasileira De Entomologia, 35, 803-812.

Anderson, R. P., Lew, D., \& Peterson, A. T. (2003). Evaluating predictive models of species' distributions: Criteria for selecting optimal models. Ecological Modelling, 162, 211-232. https://doi.org/10.1016/ S0304-3800(02)00349-6

Anthony, N. M., Johnson-Bawe, M., Jeffery, K., Clifford, S. L., Abernethy, K. A., Tutin, C. E., Lahm, S. A., White, L. J. T., Utley, J. F., Wickings, E. J., \& Bruford, M. W. (2007). The role of Pleistocene refugia and rivers in shaping gorilla genetic diversity in Central Africa. Proceedings of the National Academy of Sciences of the United States of America, 104, 20432-20436. https://doi.org/10.1073/ pnas.0704816105

Ayres, J. M. C., \& Clutton-Brock, T. H. (1992). River boundaries and species range size in Amazonian primates. American Naturalist, 140, $531-$ 537. https://doi.org/10.1086/285427

Barej, M. F., Schmitz, A., Menegon, M., Hillers, A., Hinkel, H., Boehme, W., \& Rödel, M.-O. (2011). Dusted off-the African Amietophrynus superciliaris species complex of giant toads. Zootaxa, 2772, 1-32. https://doi.org/10.11646/zootaxa.2772.1.1

Bates, H. W. (1863). The naturalist on the river Amazon. Hachette, UK: John Murray.

Bell, R. C., Parra, J. L., Badjedjea, G., Barej, M. F., Blackburn, D. C., Burger, M., Channing, A., Dehling, J. M., Greenbaum, E., Gvoždík, V., Kielgast, J., Kusamba, C., Lötters, S., McLaughlin, P. J., Nagy, Z. T., Rödel, M.O., Portik, D. M., Stuart, B. L., VanDerWal, J., ... Zamudio, K. R. (2017). Idiosyncratic responses to climate-driven forest fragmentation and marine incursions in reed frogs from Central Africa and the Gulf of Guinea Islands. Molecular Ecology, 26, 5223-5244. https://doi. org/10.1111/mec.14260

Blackburn, D. C. (2008). Biogeography and evolution of body size and life history of African frogs: Phylogeny of squeakers (Arthroleptis) and long-fingered frogs (Cardioglossa) estimated from mitochondrial 
data. Molecular Phylogenetics and Evolution, 49, 806-826. https://doi. org/10.1016/j.ympev.2008.08.015

Bohoussou, K. H., Cornette, R., Akpatou, B., Colyn, M., Peterhans, J. K., Kennis, J., \& Nicolas, V. (2015). The phylogeography of the rodent genus Malacomys suggests multiple Afrotropical Pleistocene lowland forest refugia. Journal of Biogeography, 42, 2049-2061.

Bonnefille, R., \& Riollet, G. (1988). The Kashiru pollen sequence (Burundi): Paleoclimatic implications for the last $40,000 \mathrm{yr}$ BP in tropical Africa. Quaternary Research, 30, 19-35.

Born, C., Alvarez, N., McKey, D., Ossari, S., Wickings, E. J., HossaertMcKey, M., \& Chevallier, M.-H. (2011). Insights into the biogeographical history of the Lower Guinea Forest Domain: Evidence for the role of refugia in the intraspecific differentiation of Aucoumea klaineana. Molecular Ecology, 20, 131-142. https://doi. org/10.1111/j.1365-294X.2010.04919.x

Bouckaert, R. R., \& Drummond, A. J. (2017). bModelTest: Bayesian phylogenetic site model averaging and model comparison. BMC Evolutionary Biology, 17, 1-11. https://doi.org/10.1186/s1286 2-017-0890-6

Bouckaert, R., Vaughan, T. G., Barido-Sottani, J., Duchêne, S., Fourment, M., Gavryushkina, A., \& Matschiner, M. (2019). BEAST 2.5: An advanced software platform for Bayesian evolutionary analysis. PLoS Computational Biology, 15, e1006650.

Brenac, P. (1988). Evolution de la végétation et du climat dans l'Ouest Cameroun entre 25.000 et 11.000 ans BP. Actes Xème Symposium Ass. Palynologues Langue Franwise. Travaux De La Section Des Sciences \& Techniques De L'institut Français De Pondichéry, 25, 91-103.

Budde, K. B., González-Martínez, S. C., Hardy, O. J., \& Heuertz, M. (2013). The ancient tropical rainforest tree Symphonia globulifera L. f. (Clusiaceae) was not restricted to postulated Pleistocene refugia in Atlantic Equatorial Africa. Heredity, 111, 66-76. https://doi. org/10.1038/hdy.2013.21

Burbrink, F. T., Lawson, R., \& Slowinski, J. B. (2000). Mitochondrial DNA phylogeography of the polytypic North American Rat Snake (Elaphe obsoleta): A critique of the subspecies concept. Evolution, 54, 21072118. https://doi.org/10.1111/j.0014-3820.2000.tb01253.x

Burke, K. (2001). Origin of the Cameroon Line of volcano-capped swells. The Journal of Geology, 109, 349-362. https://doi. org/10.1086/319977

Catchen, J., Hohenlohe, P. A., Bassham, S., Amores, A., \& Cresko, W. A. (2013). Stacks: An analysis tool set for population genomics. Molecular Ecology, 22, 3124-3140. https://doi.org/10.1111/mec.12354

Chardon, D., Grimaud, J. L., Rouby, D., Beauvais, A., \& Christophoul, F. (2016). Stabilization of large drainage basins over geological time scales: Cenozoic West Africa, hot spot swell growth, and the Niger River. Geochemistry, Geophysics, Geosystems, 17, 1164-1181. https:// doi.org/10.1002/2015GC006169

Charles, K. L., Bell, R. C., Blackburn, D. C., Burger, M., Fujita, M. K., Gvoždík, V., \& Portik, D. M. (2018). Sky, sea, and forest islands: Diversification in the African leaf-folding frog Afrixalus paradorsalis (Anura: Hyperoliidae) of the Lower Guineo-Congolian rainforest. Journal of Biogeography, 45, 1781-1794.

Chifman, J., \& Kubatko, L. (2014). Quartet inference from SNP data under the coalescent model. Bioinformatics, 30, 3317-3324. https://doi. org/10.1093/bioinformatics/btu530

Chippaux, J. P., \& Jackson, K. (2019). Snakes of central and western Africa. Baltimore, MD: John Hopkins University Press.

Clifford, S. L., Anthony, N. M., Bawe-Johnson, M., Abernethy, K. A., Tutin, C. E. G., White, L. J. T., Bermejo, M., Goldsmith, M. L., McFarland, K., Jeffery, K. J., Bruford, M. W., \& Wickings, E. J. (2004). Mitochondrial DNA phylogeography of western lowland gorillas (Gorilla gorilla gorilla). Molecular Ecology, 13, 1551-1565. https://doi. org/10.1111/j.1365-294X.2004.02140.x

Cobos, M. E., Peterson, A. T., Barve, N., \& Osorio-Olvera, L. (2019). Kuenm: An R package for detailed development of ecological niche models using Maxent. PeerJ, 7, e6281. https://doi.org/10.7717/ peerj.6281

Colinvaux, P. A., De Oliveira, P. E., Moreno, J. E., Miller, M. C., \& Bush, M. B. (1996). A long pollen record from lowland Amazonia: Forest and cooling in glacial times. Science (Washington), 274, 85-88. https://doi. org/10.1126/science.274.5284.85

Colinvaux, P. A., Irion, G., Räsänen, M. E., Bush, M. B., \& De Mello, J. N. (2001). A paradigm to be discarded: Geological and paleoecological data falsify the Haffer \& Prance refuge hypothesis of Amazonian speciation. Amazoniana, 16, 609-646.

Colyn, M. M. (1987). Les Primates des forêts ombrophiles de la cuvette du Zaïre: Interprétations zoogéographiques des modèles de distribution. Revue De Zoologie Africaine, Tervuren, 101, 183-196.

Colyn, M. M. (1991). L'importance zoogéographique du bassin du fleuve Zaïre pour la spéciation: Le cas des Primates Siens. Annales Musée Royal De I; Afrique Centrale, Section Zoologie, Tervuren, 264, 1-250.

Colyn, M., Gautier-Hion, A., \& Verheyen, W. (1991). A re-appraisal of palaeoenvironmental history in Central Africa: Evidence for a major fluvial refuge in the Zaire Basin. Journal of Biogeography, 18, 403-407. https://doi.org/10.2307/2845482

Couvreur, T. L. P., Dauby, G., Blach-Overgaard, A., Deblauwe, V., Dessein, S., Droissart, V., Hardy, O. J., Harris, D. J., Janssens, S. B., Ley, A. C., Mackinder, B. A., Sonké, B., Sosef, M. S. M., Stévart, T., Svenning, J.C., Wieringa, J. J., Faye, A., Missoup, A. D., Tolley, K. A., ... Sepulchre, P. (2021). Tectonics, climate and the diversification of the tropical African terrestrial flora and fauna. Biological Reviews, 96, 16-51. https://doi.org/10.1111/brv.12644

Cracraft, J. (1985). Historical biogeography and patterns of differentiation within the South American avifauna: Areas of endemism. Ornithological Monographs, 36, 49-84. https://doi. org/10.2307/40168278

Daïnou, K., Bizoux, J.-P., Doucet, J.-L., Mahy, G., Hardy, O. J., \& Heuertz, M. (2010). Forest refugia revisited: NSSRs and cpDNA sequences support historical isolation in a wide-spread African tree with high colonization capacity, Milicia excels (Moracea). Molecular Ecology, 19, 4462-4477.

Dauby, G., Duminil, J., Heuertz, M., \& Hardy, O. J. (2010). Chloroplast DNA polymorphism and phylogeography of a Central African tree species widespread in mature rainforest: Greenwayodendron suaveolens (Annonaceae). Tropical Plant Biology, 3, 4-13.

Dauby, G., Duminil, J., Heuertz, M., Koffi, G. K., Stévart, T., \& Hardy, O. J. (2014). Congruent phylogeographical patterns of eight tree species in Atlantic Central Africa provide insights into the past dynamics of forest cover. Molecular Ecology, 23, 2299-2312. https://doi. org/10.1111/mec.12724

Debout, G. D. C., Doucet, J.-L., \& Hardy, O. J. (2011). Population history and gene dispersal inferred from spatial genetic structure of a Central African timber tree, Distemonanthus benthamianus (Caesalpinioideae). Heredity, 106, 88-99. https://doi.org/10.1038/ hdy.2010.35

DeMenocal, P. B. (2004). African climate change and faunal evolution during the Pliocene-Pleistocene. Earth and Planetary Science Letters, 220, 3-24. https://doi.org/10.1016/S0012-821X(04)00003-2

Devitt, T. J., Devitt, S. E., Hollingsworth, B. D., McGuire, J. A., \& Moritz, C. (2013). Montane refugia predict population genetic structure in the Large-blotched Ensatina salamander. Molecular Ecology, 22, 1650-1665. https://doi.org/10.1111/mec.12196

Droissart, V., Dauby, G., Hardy, O. J., Deblauwe, V., Harris, D. J., Janssens, S., Mackinder, B. A., Blach-Overgaard, A., Sonké, B., Sosef, M. S. M., Stévart, T., Svenning, J.-C., Wieringa, J. J., \& Couvreur, T. L. P. (2018). Beyond trees: Biogeographical regionalization of tropical Africa. Journal of Biogeography, 45, 1153-1167. https://doi.org/10.1111/ jbi.13190

Duminil, J., Mona, S., Mardulyn, P., Doumenge, C., Walmacq, F., Doucet, J.-L., \& Hardy, O. J. (2015). Late Pleistocene molecular 
dating of past population fragmentation and demographic changes in African rain forest tree species supports the forest refuge hypothesis. Journal of Biogeography, 42, 1443-1454. https://doi. org/10.1111/jbi.12510

Dupont, L. M., \& Weinelt, M. (1996). Vegetation history of the savanna corridor between the Guinean and the Congolian rain forest during the last 150,000 years. Vegetation History and Archaeobotany, 5, $273-$ 292. https://doi.org/10.1007/BF00195296

Eriksson, J., Hohmann, G., Boesch, C., \& Vigilant, L. (2004). Rivers influence the population genetic structure of bonobos (Pan paniscus). Molecular Ecology, 13, 3425-3435. https://doi. org/10.1111/j.1365-294X.2004.02332.x

Escobar, L. E., Lira-Noriega, A., Medina-Vogel, G., \& Peterson, A. T. (2014). Potential for spread of the white-nose fungus (Pseudogymnoascus destructans) in the Americas: Use of Maxent and Niche A to assure strict model transference. Geospatial Health, 9, 221-229. https://doi. org/10.4081/gh.2014.19

Evanno, G., Regnaut, S., \& Goudet, J. (2005). Detecting the number of clusters of individuals using the software STRUCTURE: A simulation study. Molecular Ecology, 14, 2611-2620. https://doi. org/10.1111/j.1365-294X.2005.02553.x

Evans, B. J., Greenbaum, E., Kusamba, C., Carter, T. F., Tobias, M. L., Mendel, S. A., \& Kelley, D. B. (2011). Description of a new octoploid frog species (Anura: Pipidae: Xenopus) from the Democratic Republic of the Congo, with a discussion of the biogeography of African clawed frogs in the Albertine Rift. Journal of Zoology, 283, 276-290. https://doi.org/10.1111/j.1469-7998.2010.00769.x

Excoffier, L., Dupanloup, I., Huerta-Sánchez, E., Sousa, V. C., \& Foll, M. (2013). Robust demographic inference from genomic and SNP data. PLoS Genetics, 9, e1003905. https://doi.org/10.1371/journ al.pgen.1003905

Falush, D., Stephens, M., \& Pritchard, J. K. (2003). Inference of population structure using multilocus genotype data: Linked loci and correlated allele frequencies. Genetics, 164, 1567-1587.

Faye, A., Deblauwe, V., Mariac, C., Richard, D., Sonké, B., Vigouroux, Y., \& Couvreur, T. (2016). Phylogeography of the genus Podococcus (Palmae/ Arecaceae) in Central African rain forests: Climate stability predicts unique genetic diversity. Molecular Phylogenetics and Evolution, 105, 126-138. https://doi.org/10.1016/j.ympev.2016.08.005

Fjeldså, J. (1994). Geographical patterns for relict and young species of birds in Africa and South America and implications for conservation priorities. Biodiversity \& Conservation, 3, 207-226. https://doi. org/10.1007/BF00055939

Fjeldså, J., \& Bowie, R. C. (2008). New perspectives on the origin and diversification of Africa's forest avifauna. African Journal of Ecology, 46, 235-247. https://doi.org/10.1111/j.1365-2028.2008.00992.x

Flouri, T., Jiao, X., Rannala, B., \& Yang, Z. (2018). Species tree inference with BPP using genomic sequences and the multispecies coalescent. Molecular Biology and Evolution, 35, 2585-2593. https://doi. org $/ 10.1093 / \mathrm{molbev} / \mathrm{msy} 147$

Flügel, T. J., Eckardt, F. D., \& Cotterill, F. P. (2015). The present day drainage patterns of the Congo river system and their Neogene evolution. In M. J. De Wit, F. Guillocheau, \& M. C. De Wit (Eds.), Geology and resource potential of the Congo basin (pp. 315-337). Springer.

Francis, R. M. (2017). Pophelper: An R package and web app to analyze and visualize population structure. Molecular Ecology Resources, 17, 27-32.

François, O. (2016). Running structure-like population genetic analyses with R. R tutorials in Population Genetics, U. Grenoble-Alpes, 1-9.

Frichot, E., \& François, O. (2015). LEA: An R package for landscape and ecological association studies. Methods in Ecology and Evolution, 6, 925-929. https://doi.org/10.1111/2041-210X.12382

Frichot, E., Mathieu, F., Trouillon, T., Bouchard, G., \& François, O. (2014). Fast and efficient estimation of individual ancestry coefficients. Genetics, 196, 973-983. https://doi.org/10.1534/genet ics.113.160572
Frugone, M. J., López, M. E., Segovia, N. I., Cole, T. L., Lowther, A., Pistorius, P., Dantas, G. P. M., Petry, M. V., Bonadonna, F., Trathan, P., Polanowski, A., Wienecke, B., Bi, K. E., Wang-Claypool, C. Y., Waters, J. M., Bowie, R. C. K., Poulin, E., \& Vianna, J. A. (2019). More than the eye can see: Genomic insights into the drivers of genetic differentiation in Royal/Macaroni penguins across the Southern Ocean. Molecular Phylogenetics and Evolution, 139, 106563. https:// doi.org/10.1016/j.ympev.2019.106563

Gascon, C., Malcolm, J. R., Patton, J. L., da Silva, M. N. F., Bogart, J. P., Lougheed, S. C., Peres, C. A., Neckel, S., \& Boag, P. T. (2000). Riverine barriers and the geographic distribution of Amazonian species. Proceedings of the National Academy of Sciences of the United States of America, 97, 13672-13677. https://doi.org/10.1073/pnas.230136397

Gaubert, P., Njiokou, F., Ngua, G., Afiademanyo, K., Dufour, S., Malekani, J., \& Antunes, A. (2016). Phylogeography of the heavily poached African common pangolin (Pholidota, Manis tricuspis) reveals six cryptic lineages as traceable signatures of Pleistocene diversification. Molecular Ecology, 25, 5975-5993.

Girese, P., Maley, J., \& Brenac, P. (1994). Late Quaternary palaeoenvironments in the Lake Barombi Mbo (Cameroon) deduced from pollen and carbon isotopes of organic matter. Palaeogeography, Palaeoclimatology, Palaeoecology, 107, 65-78.

Gomez, C., Dussert, S., Hamon, P., Hamon, S., de Kochko, A., \& Poncet, V. (2009). Current genetic differentiation of Coffea canephora Pierre ex. A. Froehn in Guineo-Congolian African zone: Cumulative impact of ancient climatic changes and recent human activities. BMC Evolutionary Biology, 9, 167.

Gonder, M. K., Locatelli, S., Ghobrial, L., Mitchell, M. W., Kujawski, J. T., Lankester, F. J., Stewart, C.-B., \& Tishkoff, S. A. (2011). Evidence from Cameroon reveals differences in the genetic structure and histories of chimpanzee populations. Proceedings of the National Academy of Sciences of the United States of America, 108, 4766-4771. https://doi. org/10.1073/pnas.1015422108

Goudie, A. S. (2005). The drainage of Africa since the Cretaceous. Geomorphology, 67, 437-456. https://doi.org/10.1016/j.geomo rph.2004.11.008

Greenbaum, E. (2017). Emerald labyrinth: A scientist's adventures in the jungles of the Congo. Lebanon, NH: ForeEdge.

Greenbaum, E., Allen, K. E., Vaughan, E. R., Pauwels, O. S. G., Wallach, V., Kusamba, C., Muninga, W. M., Kusamba, C., Aristote, M. M., Mali, F. M. M., Badjedjea, G., Penner, J., Rödel, M.-O., Rivera, J., Sterkhova, V., Johnson, G., Tapondjou Nkonmeneck, W. P., \& Brown, R. M. (in press). Night stalkers from above: A monograph of Toxicodryas tree snakes (Squamata: Colubridae) with descriptions of two new cryptic species from Central Africa. Zootaxa.

Greenbaum, E., Portillo, F., Jackson, K., \& Kusamba, C. (2015). A phylogeny of Central African Boaedon (Serpentes: Lamprophiidae), with the description of a new cryptic species from the Albertine Rift. African Journal of Herpetology, 64, 18-38.

Gutenkunst, R. N., Hernandez, R. D., Williamson, S. H., \& Bustamante, C. D. (2009). Inferring the joint demographic history of multiple populations from multidimensional SNP frequency data. PLoS Genetics, 5, e1000695. https://doi.org/10.1371/journal.pgen.1000695

Haffer, J. R. (1969). Speciation in Amazonian forest birds. Science, 165, 131-137. https://doi.org/10.1126/science.165.3889.131

Haffer, J. R. (1974). Avian speciation in tropical South America. Publications of the Nuttall Ornithological Club, 14, 1-390.

Haffer, J. R. (1982). General aspects of the refuge theory. In G. T. Prance (Ed.), Biological diversification in the tropics (pp. 6-24). Columbia University Press.

Haffer, J. R. (1992). On the "river effect" in some forest birds of southern Amazonia. Boletim do Museu Paraense Emílio Goeldi. Nova Série. Zoologia, 8, 217-245.

Haffer, J. R. (1993). Time's cycle and time's arrow in the history of Amazonia. Compte Rendu Des Séances De La Société De Biogéographie, 69, 15-45. 
Haffer, J. R. (1997). Alternative models of vertebrate speciation in Amazonia: An overview. Biodiversity and Conservation, 6, 451-476.

Haffer, J. R. (2008). Hypotheses to explain the origin of species in Amazonia. Brazilian Journal of Biology, 68, 917-947. https://doi. org/10.1590/S1519-69842008000500003

Hale, M. L., Burg, T. M., \& Steeves, T. E. (2012). Sampling for microsatellite-based population genetic studies: 25 to 30 individuals per population is enough to accurately estimate allele frequencies. PLoS One, 7, e45170. https://doi.org/10.1371/journ al.pone. 0045170

Hampe, A., \& Jump, A. S. (2011). Climate relicts: Past, present, future. Annual Review of Ecology, Evolution, and Systematics, 42, 313-333. https://doi.org/10.1146/annurev-ecolsys-102710-145015

Harcourt, A. H., \& Wood, M. A. (2012). Rivers as barriers to primate distributions in Africa. International Journal of Primatology, 33, 168-183. https://doi.org/10.1007/s10764-011-9558-z

Hardy, O. J., Born, C., Budde, K., Daïnou, K., Dauby, G., Duminil, J., Ewédjé, E.-E., Gomez, C., Heuertz, M., Koffi, G. K., Lowe, A. J., Micheneau, C., Ndiade-Bourobou, D., Piñeiro, R., \& Poncet, V. (2013). Comparative phylogeography of African rain forest trees: A review of genetic signatures of vegetation history in the Guineo-Congolian region. Comptes Rendus Geoscience, 345, 284-296. https://doi. org/10.1016/j.crte.2013.05.001

Haus, T., Akom, E., Agwanda, B., Hofreiter, M., Roos, C., \& Zinner, D. (2013). Mitochondrial diversity and distribution of African green monkeys (Chlorocebus Gray, 1870). American Journal of Primatology, 75, 350-360.

Head, J. J., Mahlow, K., \& Müller, J. (2016). Fossil calibration dates for molecular phylogenetic analysis of snakes 2: Caenophidia, Colubroidea, Elapoidea, Colubridae. Palaeontologia Electronica, 19, 1-21. https:// doi.org/10.26879/625

Herbert, T. D., Lawrence, K. T., Tzanova, A., Peterson, L. C., CaballeroGill, R., \& Kelly, C. S. (2016). Late Miocene global cooling and the rise of modern ecosystems. Nature Geoscience, 9, 843-847. https://doi. org/10.1038/ngeo2813

Hershkovitz, P. (1977). Living new world monkeys (Platyrrhini). Chicago, IL: University of Chicago Press.

Hijmans, R. J., Cameron, S. E., Parra, J. L., Jones, P. G., \& Jarvis, A. (2005). Very high-resolution interpolated climate surfaces for global land areas. International Journal of Climatology, 25, 1965-1978. https:// doi.org/10.1002/joc.1276

Hime, P. M., Briggler, J. T., Reece, J. S., \& Weisrock, D. W. (2019). Genomic data reveal conserved female heterogamety in giant salamanders with gigantic nuclear genomes. G3: Genes|genomes|genetics, 9, 34673476. https://doi.org/10.1534/g3.119.400556

Hoang, D. T., Chernomor, O., Von Haeseler, A., Minh, B. Q., \& Vinh, L. S. (2018). UFBoot2: Improving the ultrafast bootstrap approximation. Molecular Biology and Evolution, 35, 518-522. https://doi. org $/ 10.1093 / \mathrm{molbev} / \mathrm{msx} 281$

Hofer, U., Bersier, L.-F., \& Borcard, D. (1999). Spatial organization of a herpetofauna on an elevational gradient revealed by null model tests. Ecology, 80, 976-988.

Hofer, U., Bersier, L.-F., \& Borcard, D. (2000). Ecotones and gradient as determinants of herpetofaunal community structure in the primary forest of Mount Kupe, Cameroon. Journal of Tropical Ecology, 16, 517533. https://doi.org/10.1017/S0266467400001553

Hrdina, A., \& Romportl, D. (2017). Evaluating global biodiversity hotspots-Very rich and even more endangered. Journal of Landscape Ecology, 10, 108-115. https://doi.org/10.1515/jlecol-2017-0013

Hughes, D. F., Kusamba, C., Behangana, M., \& Greenbaum, E. (2017). Integrative taxonomy of the Central African forest chameleon, Kinyongia adolfifriderici (Sauria: Chamaeleonidae), reveals underestimated species diversity in the Albertine Rift. Zoological Journal of the Linnean Society, 181, 400-438. https://doi.org/10.1093/zoolinnean/ zlx005
Huntley, J. W., Harvey, J. A., Pavia, M., Boano, G., \& Voelker, G. (2018). The systematics and biogeography of the Bearded Greenbuls (Aves: Criniger) reveals the impact of Plio-Pleistocene forest fragmentation on Afro-tropical avian diversity. Zoological Journal of the Linnean Society, 183, 672-686. https://doi.org/10.1093/zoolinnean/zlx086

Huntley, J. W., Keith, K. D., Castellanos, A. A., Musher, L. J., \& Voelker, G. (2019). Underestimated and cryptic diversification patterns across Afro-tropical lowland forests. Journal of Biogeography, 46, 381-391. https://doi.org/10.1111/jbi.13505

Igbokwe, J., Nicolas, V., Oyeyiola, A., Obadare, A., Adesina, A. S., Awodiran, M. O., Van Houtte, N., Fichet-Calvet, E., Verheyen, E., \& Olayemi, A. (2019). Molecular taxonomy of Crocidura species (Eulipotyphla: Soricidae) in a key biogeographical region for African shrews, Nigeria. Comptes Rendus Biologies, 342, 108-117. https://doi. org/10.1016/j.crvi.2019.03.004

Jacobs, B. F. (2004). Paleobotanical studies from Tropical Africa: Relevance to the evolution of forest, woodland and savannah biomes. Philosophical Transactions of the Royal Society B., 359, 1573-1583.

Jacquet, F., Denys, C., Verheyen, E., Bryja, J., Hutterer, R., Kerbis Peterhans, J. C., Stanley, W. T., Goodman, S. M., Couloux, A., Colyn, M., \& Nicolas, V. (2015). Phylogeography and evolutionary history of the Crocidura olivieri complex (Mammalia, Soricomorpha): From a forest origin to broad ecological expansion across Africa. BMC Evolutionary Biology, 15, 71. https://doi.org/10.1186/s1286 2-015-0344-y

Jacquet, F., Nicolas, V., Colyn, M., Kadjo, B., Hutterer, R., Decher, J., \& Denys, C. (2014). Forest refugia and riverine barriers promote diversification in the West African pygmy shrew (Crocidura obscurior complex, Soricomorpha). Zoologica Scripta, 43, 131-148.

Jansson, R., \& Dynesius, M. (2002). The fate of clades in a world of recurrent climatic change: Milankovitch oscillations and evolution. Annual Review of Ecology and Systematics, 33, 741-777. https://doi. org/10.1146/annurev.ecolsys.33.010802.150520

Jeffries, D. L., Copp, G. H., Lawson Handley, L., Olsén, K. H., Sayer, C. D., \& Hänfling, B. (2016). Comparing RAD seq and microsatellites to infer complex phylogeographic patterns, an empirical perspective in the Crucian carp, Carassius carassius, L. Molecular Ecology, 25, 2997-3018.

Jombart, T., \& Ahmed, I. (2011). Adegenet 1.3-1: New tools for the analysis of genome-wide SNP data. Bioinformatics, 27, 3070-3071. https:// doi.org/10.1093/bioinformatics/btr521

Jongsma, G. F. M., Barej, M. F., Barratt, C. D., Burger, M., Conradie, W., Ernst, R., Greenbaum, E., Hirschfeld, M., Leaché, A. D., Penner, J., Portik, D. M., Zassi-Boulou, A.-G., Rödel, M.-O., \& Blackburn, D. C. (2018). Diversity and biogeography of frogs in the genus Amnirana (Anura: Ranidae) across sub-Saharan Africa. Molecular Phylogenetics and Evolution, 120, 274-285. https://doi.org/10.1016/j. ympev.2017.12.006

Kalyaanamoorthy, S., Minh, B. Q., Wong, T. K., von Haeseler, A., \& Jermiin, L. S. (2017). ModelFinder: Fast model selection for accurate phylogenetic estimates. Nature Methods, 14, 587. https://doi. org $/ 10.1038 /$ nmeth.4285

Katoh, M., \& Kuma, M. (2002). MAFFT: A novel method for rapid multiple sequence alignment based on fast Fourier transform. Nucleic Acids Research, 30, 3059-3066. https://doi.org/10.1093/nar/ gkf436

Kearse, M., Moir, R., Wilson, A., Stones-Havas, S., Cheung, M., Sturrock, S., Buxton, S., Cooper, A., Markowitz, S., Duran, C., Thierer, T., Ashton, B., Meintjes, P., \& Drummond, A. (2012). Geneious Basic: An integrated and extendable desktop software platform for the organization and analysis of sequence data. Bioinformatics, 28, 1647-1649. https://doi.org/10.1093/bioinformatics/bts199

Landguth, E. L., Fedy, B. C., OYLER-McCANCE, S. J., Garey, A. L., Emel, S. L., Mumma, M., Wagner, H. H., Fortin, M.-J., \& Cushman, S. A. (2012). Effects of sample size, number of markers, and allelic richness on 
the detection of spatial genetic pattern. Molecular Ecology Resources, 12(2), 276-284. https://doi.org/10.1111/j.1755-0998.2011.03077.x

Larson, T. R., Castro, D., Behangana, M., \& Greenbaum, E. (2016). Evolutionary history of the river frog genus Amietia (Anura: Pyxicephalidae) reveals extensive diversification in Central African highlands. Molecular Phylogenetics and Evolution, 99, 168-181. https://doi.org/10.1016/j.ympev.2016.03.017

Lawson, R., Slowinski, J. B., Crother, B. I., \& Burbrink, F. T. (2005). Phylogeny of the Colubroidea (Serpentes): New evidence from mitochondrial and nuclear genes. Molecular Phylogenetics and Evolution, 37, 581-601. https://doi.org/10.1016/j.ympev.2005.07.016

Leaché, A. D., \& Fujita, M. K. (2010). Bayesian species delimitation in West African forest geckos (Hemidactylus fasciatus). Proceedings of the Royal Society of London B. Biological Sciences, 277, 3071-3077.

Leaché, A. D., Grummer, J. A., Miller, M., Krishnan, S., Fujita, M. K., Böhme, W., \& Ofori-Boateng, C. (2017). Bayesian inference of species diffusion in the West African Agama agama species group (Reptilia, Agamidae). Systematics and Biodiversity, 15, 192-203.

Leaché A. D., Oaks J. R., Ofori-Boateng C., Fujita M. K. (2020). Comparative phylogeography of West African amphibians and reptiles. Evolution, 74, 716-724. https://doi.org/10.1111/evo.13941

Leaché, A. D., Portik, D. M., Rivera, D., Rödel, M.-O., Penner, J., Gvoždík, V., Greenbaum, E., Jongsma, G. F. M., Ofori-Boateng, C., Burger, M., Eniang, E. A., Bell, R. C., \& Fujita, M. K. (2019). Exploring rain forest diversification using demographic model testing in the African foam-nest treefrog Chiromantis rufescens. Journal of Biogeography, 46, 2706-2721.

Levinsky, I., Araújo, M. B., Nogués-Bravo, D., Haywood, A. M., Valdes, P. J., \& Rahbek, C. (2013). Climate envelope models suggest spatiotemporal co-occurrence of refugia of African birds and mammals. Global Ecology and Biogeography, 22, 351-363. https://doi. org/10.1111/geb.12045

Ley, A. C., Dauby, G., Köhler, J., Wypior, C., Röser, M., \& Hardy, O. J. (2014). Comparative phylogeography of eight herbs and lianas (Marantaceae) in central African rainforests. Frontiers in Genetics, 5, 403. https://doi.org/10.3389/fgene.2014.00403

Ley, A. C., Heuertz, M., \& Hardy, O. J. (2016). The evolutionary history of Central African rain forest plants: Phylogeographical insights from sister species in the climber genus Haumania (Marantaceae). Journal of Biogeography, 44, 308-321.

Linder, H. P., de Klerk, H. M., Born, J., Burgess, N. D., Fjeldså, J., \& Rahbek, C. (2012). The partitioning of Africa: Statistically defined biogeographical regions in sub-Saharan Africa. Journal of Biogeography, 39, 1189-1205. https://doi.org/10.1111/j.1365-2699.2012.02728.x

Lowe, A. J., Harris, D., Dormontt, E., \& Dawson, I. K. (2010). Testing putative African tropical forest refugia using chloroplast and nuclear DNA phylogeography. Tropical Plant Biology, 3, 50-58. https://doi. org/10.1007/s12042-010-9045-2

Macgregor, D. (2015). History of the development of the East African Rift System: A series of interpreted maps through time. Journal of African Earth Sciences, 101, 232-252. https://doi.org/10.1016/j.jafre arsci.2014.09.016

Maley, J. (1987). Fragmentation de la forêt dense humide africaine et extension des biotopes montagnards au Quatemaire récent: Nouvelles données polliniques et chronologiques. Implications paléo-climatiques et biogéographiques. Palaeoecology of Africa, 18, 307-334.

Maley, J. (1989). Late Quaternary climatic changes in the African rain forest: Forest refugia and the major role of sea surface temperature variations. In M. Leinen \& M. Sarnthein (Eds.), Paleoclimatology and paleometeorology: Modern and past patterns of global atmospheric transport (pp. 585-616). Springer.

Maley, J. (1991). The African rain forest vegetation and palaeoenvironments during late Quaternary. Climatic Change, 19, 79-98. https:// doi.org/10.1007/BF00142216
Maley, J. (1996). The African rain forest - Main characteristics of changes in vegetation and climate from the Upper Cretaceous to the Quaternary. Proceedings of the Royal Society of Edinburgh, 104, 31-73. https://doi.org/10.1017/S0269727000006114

Maley, J., \& Brénac, P. (1987). Analyses polliniques préliminaires du Quaternaire récent de l'Ouest Cameroun: Mise en évidence de refuges forestiers et discussion des problèmes paléoclimatiques. Mémoires Et Travaux De L'institut De Montpellier, 17, 129-142.

Maley, J., \& Brenac, P. (1998). Vegetation dynamics, palaeoenvironments and climatic changes in the forests of western Cameroon during the last 28,000 years BP. Review of Palaeobotany and Palynology, 99, 157-187. https://doi.org/10.1016/S0034 -6667(97)00047-X

Maley, J., \& Livingstone, D. A. (1983). Extension d'un élément montagnard dans le Sud du Ghana (Afrique de l'Ouest) au Pléistocène supérieur et à l'Holocène inférieur: Premières données polliniques. Comptes Rendus De L'académie Des Sciences, Paris, 296, 1287-1292.

Marks, B. D. (2010). Are lowland rainforests really evolutionary museums? Phylogeography of the green hylia (Hylia prasina) in the Afrotropics. Molecular Phylogenetics and Evolution, 55, 178-184. https://doi.org/10.1016/j.ympev.2009.10.027

Marzoli, A., Piccirillo, E. M., Renne, P. R., Bellieni, G., lacumin, M., Nyobe, J. B., \& Tongwa, A. T. (2000). The Cameroon Volcanic Line revisited: Petrogenesis of continental basaltic magmas from lithospheric and asthenospheric mantle sources. Journal of Petrology, 41, 87-109. https://doi.org/10.1093/petrology/41.1.87

Mayr, E. (1942). Systematics and the origin of species from the viewpoint of a zoologist. New York, NY: Columbia University Press.

Mayr, E., \& O'Hara, R. J. (1986). The biogeographic evidence supporting the Pleistocene forest refuge hypothesis. Evolution, 40, 55-67. https://doi.org/10.1111/j.1558-5646.1986.tb05717.x

Menegon, M., Loader, S. P., Marsden, S. J., Branch, W. R., Davenport, T. R. B., \& Ursenbacher, S. (2014). The genus Atheris (Serpentes: Viperidae) in East Africa: Phylogeny and the role of rifting and climate in shaping the current pattern of species diversity. Molecular Phylogenetics and Evolution, 79, 12-22. https://doi.org/10.1016/j.ympev.2014.06.007

Mitchell, M. W., Locatelli, S., Ghobrial, L., Pokempner, A. A., Sesink Clee, P. R., Abwe, E. E., Nicholas, A., Nkembi, L., Anthony, N. M., Morgan, B. J., Fotso, R., Peeters, M., Hahn, B. H., \& Gonder, M. K. (2015). The population genetics of wild chimpanzees in Cameroon and Nigeria suggests a positive role for selection in the evolution of chimpanzee subspecies. BMC Evolutionary Biology, 15, 3. https://doi.org/10.1186/ s12862-014-0276-y

Mittermeier, R. A., Myers, N., \& Mittermeier, C. G. (2000). Hotspots: Earth's biologically richest and most endangered terrestrial ecoregions. Chicago, IL: University of Chicago Press.

Mittermeier, R. A., Turner, W. R., Larsen, F. W., Brooks, T. M., \& Gascon, C. (2011). Global biodiversity conservation: The critical role of hotspots. In F. E. Zachos \& J. C. Habel (Eds.), Biodiversity hotspots - Distribution and protection of conservation priority areas (pp. 3-22). Springer.

Muniz, F. L., Campos, Z., Hernández Rangel, S. M., Martínez, J. G., Souza, B. C., De Thoisy, B., Botero-Arias, R., Hrbek, T., \& Farias, I. P. (2018). Delimitation of evolutionary units in Cuvier's dwarf caiman, Paleosuchus palpebrosus (Cuvier, 1807): Insights from conservation of a broadly distributed species. Conservation Genetics, 19, 599-610. https://doi.org/10.1007/s10592-017-1035-6

Myers, N. (1988). Threatened biotas: "Hot spots" in tropical forests. The Environmentalist, 8, 187-208. https://doi.org/10.1007/BF02240252

Nagy, Z. T., Kusamba, Z. C., Tungaluma, G. G., Lokasola, A. L., Kolby, J., \& Kielgast, J. (2011). Foraging acrobatics of Toxicodryas blandingii in the Democratic Republic of the Congo. Herpetology Notes, 4, 91-92.

Nash, H. C., Low, G. W., Choo, S. W., Chong, J. L., Semiadi, G., Hari, R., Sulaiman, M. H., Turvey, S. T., Evans, T. A., \& Rheindt, F. E. (2018). 
Conservation genomics reveals possible illegal trade routes and admixture across pangolin lineages in Southeast Asia. Conservation Genetics, 19, 1083-1095. https://doi.org/10.1007/s1059 2-018-1080-9

Nazareno, A. G., Bemmels, J. B., Dick, C. W., \& Lohmann, L. G. (2017). Minimum sample sizes for population genomics: An empirical study from an Amazonian plant species. Molecular Ecology Resources, 17, 1136-1147. https://doi.org/10.1111/1755-0998.12654

Nelson, M. R., Wegmann, D., Ehm, M. G., Kessner, D., St. Jean, P., Verzilli, C., Shen, J., Tang, Z., Bacanu, S.-A., Fraser, D., Warren, L., Aponte, J., Zawistowski, M., Liu, X., Zhang, H., Zhang, Y., Li, J., Li, Y., Li, L. I., ... Mooser, V. (2012). An abundance of rare functional variants in 202 drug target genes sequenced in 14,002 people. Science, $337,100-$ 104. https://doi.org/10.1126/science.1217876

Nguyen, L. T., Schmidt, H. A., von Haeseler, A., \& Minh, B. Q. (2014). IQ-TREE: A fast and effective stochastic algorithm for estimating maximum-likelihood phylogenies. Molecular Biology and Evolution, 32, 268-274. https://doi.org/10.1093/molbev/msu300

Nicolas, V., Akpatou, B., Wendelen, W., Kerbis peterhans, J., Olayemi, A., Decher, J., Missoup, A.-D., Denys, C., Barriere, P., Cruaud, C., \& Colyn, M. (2010). Molecular and morphometric variation in two sibling species of the genus Praomys (Rodentia: Muridae): Implications for biogeography. Zoological Journal of the Linnean Society, 160, 397419. https://doi.org/10.1111/j.1096-3642.2009.00602.x

Nicolas, V., Missoup, A. D., Colyn, M., Cruaud, C., \& Denys, C. (2012). West-Central African Pleistocene lowland forest evolution revealed by the phylogeography of Misonne's soft-furred mouse. African Zoology, 47, 100-112.

Nicolas, V., Missoup, A. D., Denys, C., Kerbis Peterhans, J., Katuala, P., Couloux, A., \& Colyn, M. (2011). The roles of rivers and Pleistocene refugia in shaping genetic diversity in Praomys misonnei in tropical Africa. Journal of Biogeography, 38, 191-207. https://doi. org/10.1111/j.1365-2699.2010.02399.x

Onadeko, A. B., \& Rödel, M.-O. (2009). Anuran surveys in south-western Nigeria. Salamandra, 45, 1-14.

Paris, J. R., Stevens, J. R., \& Catchen, J. M. (2017). Lost in parameter space: A road map for stacks. Methods in Ecology and Evolution, 8, 1360-1373.

Patton, J. L., \& Silva, M. F. (2005). The history of Amazonian mammals: Mechanisms and timing of diversification. In E. Bermingham, C. W. Dick, \& C. Moritz (Eds.), Tropical rainforests: Past, present and future (pp. 107-126). The University of Chicago Press.

Paul, J. D., Roberts, G. G., \& White, N. (2014). The African landscape through space and time. Tectonics, 33, 898-935. https://doi. org/10.1002/2013TC003479

Penner, J., Augustin, M., \& Rödel, M.-O. (2019). Modelling the spatial baseline for amphibian conservation in West Africa. Acta Oecologica, 84, 31-40. https://doi.org/10.1016/j.actao.2017.11.018

Penner, J., Wegmann, M., Hillers, A., Schmidt, M., \& Rödel, M.-O. (2011). A hotspot revisited - A biogeographical analysis of West African amphibians. Diversity and Distribution, 17, 1077-1088. https://doi. org/10.1111/j.1472-4642.2011.00801.x

Peterson, A. T., Papeş, M., \& Soberón, J. (2008). Rethinking receiver operating characteristic analysis applications in ecological niche modeling. Ecological Modelling, 213, 63-72. https://doi.org/10.1016/j. ecolmodel.2007.11.008

Peter B. M., Slatkin M. (2013). Detecting range expansions from genetic data. Evolution, 67, 3274-3289. https://doi.org/10.1111/evo.12202

Peter B. M., Slatkin M. (2015). The effective founder effect in a spatially expanding population. Evolution, 69, 721-734. https://doi. org/10.1111/evo.12609

Peterson, B. K., Weber, J. N., Kay, E. H., Fisher, H. S., \& Hoekstra, H. E. (2012). Double digest RADseq: An inexpensive method for de novo discovery and genotyping in model and non-model species. PLoS One, 7, e37135.
Phillips, S. J., Anderson, R. P., \& Schapire, R. E. (2006). Maximum entropy modeling of species geographic distributions. Ecological Modelling, 190, 231-259. https://doi.org/10.1016/j.ecolmodel.2005.03.026

Plana, V. (2004). Mechanisms and tempo of evolution in the African Guineo-Congolian rainforest. Philosophical Transactions of the Royal Society of London. Series B: Biological Sciences, 359, 1585-1594.

Porras-Hurtado, L., Ruiz, Y., Santos, C., Phillips, C., Carracedo, Á., \& Lareu, M. (2013). An overview of STRUCTURE: Applications, parameter settings, and supporting software. Frontiers in Genetics, 4, 98. https://doi.org/10.3389/fgene.2013.00098

Portik, D. M., Leaché, A. D., Rivera, D., Barej, M. F., Burger, M., Hirschfeld, M., Rödel, M.-O., Blackburn, D. C., \& Fujita, M. K. (2017). Evaluating mechanisms of diversification in a Guineo-Congolian tropical forest frog using demographic model selection. Molecular Ecology, 26, 5245-5263. https://doi.org/10.1111/mec.14266

Portillo, F., Stanley, E. L., Branch, W. R., Conradie, W., Rödel, M.-O., Penner, J., Barej, M. F., Kusamba, C., Muninga, W. M., Aristote, M. M., Bauer, A. M., Trape, J.-F., Nagy, Z. T., Carlino, P., Pauwels, O. S. G., Menegon, M., Ineich, I., Burger, M., Zassi-Boulou, A.-G., ... Greenbaum, E. (2019). Evolutionary history of burrowing asps (Lamprophiidae: Atractaspidinae) with emphasis on fang evolution and prey selection. PLoS One, 14, e0214889. https://doi.org/10.1371/ journal.pone.0214889

Prance, G. T. (1982). Biological diversification in the tropics. New York, NY: Columbia University Press.

Pritchard, J. K., Stephens, M., \& Donnelly, P. (2000). Inference of population structure using multilocus genotype data. Genetics, 155, 945-959.

Pudlo, P., Marin, J. M., Estoup, A., Cornuet, J. M., Gautier, M., \& Robert, C. P. (2015). Reliable $A B C$ model choice via random forests. Bioinformatics, 32, 859-866. https://doi.org/10.1093/bioinforma tics/btv684

Puechmaille, S. J. (2016). The program structure does not reliably recover the correct population structure when sampling is uneven: Subsampling and new estimators alleviate the problem. Molecular Ecology Resources, 16, 608-627.

Pyron, R. A., Burbrink, F. T., \& Wiens, J. J. (2013). A phylogeny and revised classification of Squamata, including 4161 species of lizards and snakes. BMC Evolutionary Biology, 13, 93. https://doi. org/10.1186/1471-2148-13-93

Qu, W. M., Liang, N., Wu, Z. K., Zhao, Y. G., \& Chu, D. (2020). Minimum sample sizes for invasion genomics: Empirical investigation in an invasive whitefly. Ecology and Evolution, 10, 38-49. https://doi. org/10.1002/ece3.5677

Rambaut, A., Drummond, A. J., Xie, D., Baele, G., \& Suchard, M. A. (2018). Posterior summarization in Bayesian phylogenetics using Tracer 1.7. Systematic Biology, 67, 901-904. https://doi.org/10.1093/sysbio/ syy032

Rannala, B., \& Yang, Z. (2013). Improved reversible jump algorithms for Bayesian species delimitation. Genetics, 194, 245-253. https://doi. org/10.1534/genetics.112.149039

R Core Team (2019). R: A language and environment for statistical computing. R Foundation for Statistical Computing, Vienna, Austria, https:// www.R-project.org/

Reijers T. (2011). Stratigraphy and sedimentology of the Niger Delta. Geologos, 17, 133-162. https://doi.org/10.2478/v1011 8-011-0008-3

Reusch, A. M., Nyblade, A. A., Wiens, D. A., Shore, P. J., Ateba, B., Tabod, C. T., \& Nnange, J. M. (2010). Upper mantle structure beneath Cameroon from body wave tomography and the origin of the Cameroon Volcanic Line. Geochemistry, Geophysics, Geosystems, 11, Q10W07. https://doi.org/10.1029/2010GC003200

Richards, P. W. (1963). Ecological notes on West African vegetation. II. Lowland forest of the southern Bakundu Forest Reserve. Journal of Ecology, 51, 123-149. https://doi.org/10.2307/2257510 
Richardson, J. E., Pennington, R. T., Pennington, T. D., \& Hollingsworth, P. M. (2001). Recent and rapid diversification of a species-rich genus of Neotropical trees. Science, 293, 2242-2245.

Rietkerk, M., Ketner, P., \& De Wilde, J. (1995). Caesalpinioideae and the study of forest refuges in Gabon: Preliminary results. Bulletin Du Museum National D'histoire Naturelle, Paris, Adansonia, 17, 95-105.

Robbrecht, E. (1996). Geography of African Rubiaceae with reference to glacial rain forest refuges. In L. J. G. van der Maesen, X. M. van der Burgt, \& J. M. van Medenbach de Rooy (Eds.), The biodiversity of African plants (pp. 564-581). Kluwer.

Rödel, M.-O., Emmrich, M., Penner, J., Schmitz, A., \& Barej, M. F. (2014). The taxonomic status of two West African Leptopelis species: L. macrotis Schiøtz, 1967 and L. spiritusnoctis Rödel, 2007 (Amphibia: Anura: Arthroleptidae). Zoosystematics and Evolution, 90, 21-32. https://doi. org/10.3897/zse.90.7120

Schmidt, K. P. (1923). Contributions to the herpetology of the Belgian Congo based on the collection of the American Museum Congo Expedition, 1909-1915. Part II. Snakes, with field notes by Herbert Lang and James P. Chapin. Bulletin of the American Museum of Natural History, 49, 1-146.

Shafer, A. B., Peart, C. R., Tusso, S., Maayan, I., Brelsford, A., Wheat, C. W., \& Wolf, J. B. (2017). Bioinformatic processing of RAD-seq data dramatically impacts downstream population genetic inference. Methods in Ecology and Evolution, 8, 907-917. https://doi. org/10.1111/2041-210X.12700

Sick, H. (1967). Rios e enchentes na Amazônia como obstáculo para a avifauna. Atas do Simpósio Sobre a Biota Amazônica, 5, 495-520.

Siddig, A. A. (2019). Why is biodiversity data-deficiency an ongoing conservation dilemma in Africa? Journal for Nature Conservation, 50, 125719. https://doi.org/10.1016/j.jnc.2019.125719

Smith, M. L., \& Carstens, B. C. (2020). Process-based species delimitation leads to identification of more biologically relevant species. Evolution, 74, 216-229. https://doi.org/10.1111/evo.13878

Smith, M. L., Ruffley, M., Espíndola, A., Tank, D. C., Sullivan, J., \& Carstens, B. C. (2017). Demographic model selection using random forests and the site frequency spectrum. Molecular Ecology, 26, 4562-4573. https://doi.org/10.1111/mec.14223

Soberón, J., \& Peterson, A. T. (2005). Interpretation of models of fundamental ecological niches and species' distributional areas. Biodiversity Informatics, 2, 1-10. https://doi.org/10.17161/bi.v2i0.4

Sosef, M. S. M. (1991). New species of Begonia in Africa and their relevance to the study of glacial rain forest refuges. Wageningen Agricultural University Papers, 91, 120-151.

Sowunmi, M. A. (1991). Late Quaternary environments in equatorial Africa: Palynological evidence. Palaeoecology of Africa, 22, 213-238.

Spawls, S., Howell, K., Hinkel, H., \& Menegon, M. (2018). Field guide to east African reptiles. London, England: Bloomsbury Publishing.

Stankiewicz, J., \& de Wit, M. J. (2006). A proposed drainage evolution model for Central Africa-Did the Congo flow east? Journal of African Earth Sciences, 44, 75-84. https://doi.org/10.1016/j.jafre arsci.2005.11.008

Subramanian, S. (2016). The effects of sample size on population genomic analyses - Implications for the tests of neutrality. BMC Genomics, 17, 1-13. https://doi.org/10.1186/s12864-016-2441-8

Sukumaran, J., \& Holder, M. T. (2010). DendroPy: A Python library for phylogenetic computing. Bioinformatics, 26, 1569-1571. https://doi. org/10.1093/bioinformatics/btq228

Swofford, D. L. (2003). PAUP*. Phylogenetic Analysis Using Parsimony (*and other methods), Version 4. Sinauer Associates.

Takemoto, H., Kawamoto, Y., \& Furuichi, T. (2015). How did bonobos come to range south of the Congo River? Reconsideration of the divergence of Pan paniscus from other Pan populations. Evolutionary Anthropology: Issues, News, and Reviews, 24, 170-184.

Telfer, P. T., Souquiere, S., Clifford, S. L., Abernethy, K. A., Bruford, M. W., Disotell, T. R., \& Wickings, E. J. (2003). Molecular evidence for deep phylogenetic divergence in Mandrillus sphinx. Molecular Ecology, 12, 2019-2024.

Terhorst, J., \& Song, Y. S. (2015). Fundamental limits on the accuracy of demographic inference based on the sample frequency spectrum. Proceedings of the National Academy of Sciences of the United States of America, 112, 7677-7682. https://doi.org/10.1073/pnas.15037 17112

Tolley, K. A., Alexander, G. J., Branch, W. R., Bowles, P., \& Maritz, B. (2016). Conservation status and threats for African reptiles. Biological Conservation, 204, 63-71. https://doi.org/10.1016/j. biocon.2016.04.006

Tosi, A. J. (2008). Forest monkeys and Pleistocene refugia: A phylogeographic window onto the disjunct distribution of the Chlorocebus Ihoesti species group. Zoological Journal of the Linnean Society, 154, 408-418.

Vanzolini, P. E. (1973). Paleoclimates, relief, and species multiplication in equatorial forests. In B. J. Meggers, E. S. Ayensu, \& W. D. Duckworth (Eds.), Tropical forest ecosystems in Africa and South America: A comparative review (pp. 255-258). Smithsonian Press.

Vanzolini, P. E., \& Williams, E. E. (1970). South American anoles: Geographic differentiation and evolution of the Anolis chrysolepis species group (Sauria, Iguanidae). Arquivos De Zoologia, São Paulo, 19, 291-298.

Vitorino, L. C., Lima-Ribeiro, M. S., Terribile, L. C., \& Collevatti, R. G. (2016). Demographical history and palaeodistribution modelling show range shift towards Amazon Basin for a Neotropical tree species in the LGM. BMC Evolutionary Biology, 16, 213-228. https://doi. org/10.1186/s12862-016-0779-9

Wallace, A. R. (1853). A narrative of travels on the Amazon and Rio Negro. Reeve.

Warren, D. L., \& Seifert, S. N. (2011). Ecological niche modeling in Maxent: The importance of model complexity and the performance of model selection criteria. Ecological Applications, 21, 335-342. https://doi.org/10.1890/10-1171.1

Weinell, J. L., Barley, A. J., Siler, C. D., Orlov, N. L., Ananjeva, N. B., Oaks, J. R., Burbrink, F. T., \& Brown, R. M. (2020). Phylogenetic relationships and biogeographic range evolution in Cat-eyed Snakes Boiga (Serpentes: Colubridae). Zoological Journal of the Linnaean Society, 2020, 1-16. https://doi.org/10.1093/zoolinnean/zlaa090

Weir, J. T. (2006). Divergent timing and patterns of species accumulation in lowland and highland neotropical birds. Evolution, 60, 842-855. https://doi.org/10.1111/j.0014-3820.2006.tb01161.x

White, F. (1979). The Guineo-Congolian Region and its relationships to other phytochoria. Bulletin Du Jardin Botanique National De Belgique/ Bulletin Van De Nationale Plantentuin Van Belgie, 49, 11-55. https:// doi.org/10.2307/3667815

White, F. (1981). The history of the Afromontane archipelago and the scientific need for its conservation. African Journal of Ecology, 19, 33-54. https://doi.org/10.1111/j.1365-2028.1981.tb00651.x

Wieczorek, A. M., Drewes, R. C., \& Channing, A. (2000). Biogeography and evolutionary history of Hyperolius species: Application of molecular phylogeny. Journal of Biogeography, 27, 1231-1243. https://doi. org/10.1046/j.1365-2699.2000.00491.x

Wüster, W., Chirio, L., Trape, J.-F., Ineich, I., Jackson, K., Greenbaum, E., Barron, C., Kusamba, C., Nagy, Z. T., Storey, R., Hall, C., Wüster, C. E., Barlow, A., \& Broadley, D. G. (2018). Integration of nuclear and mitochondrial gene sequences and morphology reveals unexpected diversity in the forest cobra (Naja melanoleuca) species complex in Central and West Africa (Serpentes: Elapidae). Zootaxa, 4455, 68-98. https://doi.org/10.11646/zootaxa.4455.1.3

Yang, Z. (2015). The BPP program for species tree estimation and species delimitation. Current Zoology, 61, 854-865. https://doi.org/10.1093/ czoolo/61.5.854

Yang, Z., \& Flouri, T. (2020). BP\&P version 4.2 documentation. Retrieved from https://github.com/bpp/bpp 
Yang, Z., \& Rannala, B. (2010). Bayesian species delimitation using multilocus sequence data. Proceedings of the National Academy of Sciences, 107(20), 9264-9269. https://doi.org/10.1073/pnas.09130 22107

Yannic, G., Pellissier, L., Ortego, J., Lecomte, N., Couturier, S., Cuyler, C., Dussault, C., Hundertmark, K. J., Irvine, R. J., Jenkins, D. A., Kolpashikov, L., Mager, K., Musiani, M., Parker, K. L., Røed, K. H., Sipko, T., Pórisson, S. G., Weckworth, B. V., Guisan, A., ... Côté, S. D. (2014). Genetic diversity in caribou linked to past and future climate change. Nature Climate Change, 4, 132-137. https://doi.org/10.1038/ nclimate2074

Zimkus, B. M., \& Gvoždík, V. (2013). Sky Islands of the Cameroon Volcanic Line: A diversification hot spot for puddle frogs (Phrynobatrachidae: Phrynobatrachus). Zoologica Scripta, 42, 591-611.

Zimkus, B. M., Lawson, L. P., Barej, M. F., Barratt, C. D., Channing, A., Dash, K. M., Dehling, J. M., Du Preez, L., Gehring, P.-S., Greenbaum, E., Gvoždík, V., Harvey, J., Kielgast, J., Kusamba, C., Nagy, Z. T., Pabijan, M., Penner, J., Rödel, M.-O., Vences, M., \& Lötters, S. (2017). Leapfrogging into new territory: How Mascarene ridged frogs diversified across Africa and Madagascar to maintain their ecological niche. Molecular Phylogenetics and Evolution, 106, 254-269. https:// doi.org/10.1016/j.ympev.2016.09.018
Zimkus, B. M., Rödel, M. O., \& Hillers, A. (2010). Complex patterns of continental speciation: Molecular phylogenetics and biogeography of sub-Saharan puddle frogs (Phrynobatrachus). Molecular Phylogenetics and Evolution, 55, 883-900. https://doi.org/10.1016/j. ympev.2009.12.012

Zwickl, D. J., \& Hillis, D. M. (2002). Increased taxon sampling greatly reduces phylogenetic error. Systematic Biology, 51, 588-598. https:// doi.org/10.1080/10635150290102339

\section{SUPPORTING INFORMATION}

Additional supporting information may be found online in the Supporting Information section.

How to cite this article: Allen KE, Greenbaum E, Hime PM, et al. Rivers, not refugia, drove diversification in arboreal, sub-Saharan African snakes. Ecol Evol. 2021;11:6133-6152. https://doi.org/10.1002/ece3.7429 